Atmos. Chem. Phys., 13, 6533-6552, 2013

www.atmos-chem-phys.net/13/6533/2013/

doi:10.5194/acp-13-6533-2013

(c) Author(s) 2013. CC Attribution 3.0 License.

\title{
Stratospheric aerosols from the Sarychev volcano eruption in the 2009 Arctic summer
}

\author{
F. Jégou ${ }^{1}$, G. Berthet ${ }^{1}$, C. Brogniez ${ }^{2}$, J.-B. Renard ${ }^{1}$, P. François ${ }^{2}$, J. M. Haywood ${ }^{3,4,5}$, A. Jones ${ }^{4}$, Q. Bourgeois ${ }^{6}$, \\ T. Lurton ${ }^{1}$, F. Auriol ${ }^{2}$, S. Godin-Beekmann ${ }^{7}$, C. Guimbaud ${ }^{1}$, G. Krysztofiak ${ }^{1}$, B. Gaubicher ${ }^{1}$, M. Chartier ${ }^{1}$, \\ L. Clarisse ${ }^{8}$, C. Clerbaux ${ }^{7}$, J. Y. Balois ${ }^{2}$, C. Verwaerde ${ }^{2}$, and D. Daugeron ${ }^{1}$ \\ ${ }^{1}$ Laboratoire de Physique et Chimie de l'Environnement et de l'Espace, Université d'Orléans, CNRS/INSU UMR7328, \\ Orléans, France \\ ${ }^{2}$ Laboratoire d'Optique Atmosphérique, Université Lille 1 Sciences et Technologies, CNRS/INSU UMR8518, Villeneuve \\ d'Ascq, France \\ ${ }^{3}$ Observational Based Research, Met Office, Exeter, UK \\ ${ }^{4}$ Earth System and Mitigation Science, Met Office Hadley Centre, Exeter, UK \\ ${ }^{5}$ College of Engineering, Mathematics, and Physical Sciences, University of Exeter, Exeter, UK \\ ${ }^{6}$ Center for Climate Systems Modeling, Institute for Atmospheric and Climate Science, ETH Zürich, Zürich, Switzerland \\ ${ }^{7}$ Laboratoire Atmosphères Milieux Observations Spatiales, UPMC, Université Paris 06, Université Versailles Saint Quentin, \\ CNRS/INSU UMR8190, LATMOS-IPSL, Paris, France \\ ${ }^{8}$ Spectroscopie de l'Atmosphère, Service de Chimie Quantique et Photophysique, Université Libre de Bruxelles, Brussels, \\ Belgium
}

Correspondence to: F. Jégou (fabrice.jegou@orleans.cnrs.fr)

Received: 30 November 2012 - Published in Atmos. Chem. Phys. Discuss.: 8 February 2013

Revised: 29 May 2013 - Accepted: 9 June 2013 - Published: 10 July 2013

\begin{abstract}
Aerosols from the Sarychev volcano eruption (Kuril Islands, northeast of Japan) were observed in the Arctic lower stratosphere a few days after the strongest $\mathrm{SO}_{2}$ injection which occurred on 15 and 16 June 2009. From the observations provided by the Infrared Atmospheric Sounding Interferometer (IASI) an estimated $0.9 \mathrm{Tg}$ of sulphur dioxide was injected into the upper troposphere and lower stratosphere (UTLS). The resultant stratospheric sulphate aerosols were detected from satellites by the Optical Spectrograph and Infrared Imaging System (OSIRIS) limb sounder and by the Cloud-Aerosol Lidar with Orthogonal Polarization (CALIOP) and from the surface by the Network for the Detection of Atmospheric Composition Changes (NDACC) lidar deployed at OHP (Observatoire de Haute-Provence, France). By the first week of July the aerosol plume had spread out over the entire Arctic region. The Sarychev-induced stratospheric aerosol over the Kiruna region (north of Sweden) was measured by the Stratospheric and Tropospheric Aerosol Counter (STAC) during eight balloon flights planned in August and Septem-
\end{abstract}

ber 2009. During this balloon campaign the Micro Radiomètre Ballon (MicroRADIBAL) and the Spectroscopie d'Absorption Lunaire pour l'Observation des Minoritaires Ozone et NOx (SALOMON) remote-sensing instruments also observed these aerosols. Aerosol concentrations returned to near-background levels by spring 2010 . The effective radius, the surface area density (SAD), the aerosol extinction, and the total sulphur mass from STAC in situ measurements are enhanced with mean values in the range $0.15-0.21 \mu \mathrm{m}, 5.5-14.7 \mu \mathrm{m}^{2} \mathrm{~cm}^{-3}, 5.5-29.5 \times 10^{-4} \mathrm{~km}^{-1}$, and $4.9-12.6 \times 10^{-10} \mathrm{~kg}[\mathrm{~S}] \mathrm{kg}^{-1}$ [air], respectively, between $14 \mathrm{~km}$ and $18 \mathrm{~km}$. The observed and modelled e-folding time of sulphate aerosols from the Sarychev eruption is around 70-80 days, a value much shorter than the 12-14 months calculated for aerosols from the 1991 eruption of Mt Pinatubo. The OSIRIS stratospheric aerosol optical depth (AOD) at $750 \mathrm{~nm}$ is enhanced by a factor of 6 , with a value of 0.02 in late July compared to 0.0035 before the eruption. The HadGEM2 and MIMOSA model outputs indicate that aerosol layers in polar region up to $14-15 \mathrm{~km}$ are largely 
modulated by stratosphere-troposphere exchange processes. The spatial extent of the Sarychev plume is well represented in the HadGEM2 model with lower altitudes of the plume being controlled by upper tropospheric troughs which displace the plume downward and upper altitudes around $18-20 \mathrm{~km}$, in agreement with lidar observations. Good consistency is found between the HadGEM2 sulphur mass density and the value inferred from the STAC observations, with a maximum located about $1 \mathrm{~km}$ above the tropopause ranging from 1 to $\left.2 \times 10^{-9} \mathrm{~kg} \mathrm{~S}\right] \mathrm{kg}^{-1}$ [air], which is one order of magnitude higher than the background level.

\section{Introduction}

The climate effects of volcanic eruptions are well acknowledged (Robock, 2000). These effects are due to the production of a layer of sulphate aerosols in the lower stratosphere, which efficiently backscatters solar radiation, increases the planetary albedo, and causes cooling at the surface. For these radiative effects to accumulate, the aerosols must remain in the atmosphere for an extended period of time. The stratospheric aerosol e-folding lifetime is strongly dependent on the altitude of injection. The residence time of aerosols is about 1 week when the injection occurs only in the troposphere and varies from a few months for moderate stratovolcanic eruptions to more than $1 \mathrm{yr}$ for major eruptions (volcanic explosive index $>6$ ). Solomon et al. (2011) showed that moderate eruptions from stratovolcanoes are likely to modulate the "background" aerosol layer in the lower stratosphere. In particular, the recurrent eruptions have resulted in a net negative radiative forcing in the period subsequent to 2000 , offsetting the positive radiative forcing owing to increased concentrations of well-mixed greenhouse gases and hence global warming. It is therefore important to monitor and characterize the physical properties of stratospheric aerosols formed from this type of eruption so as to quantify their radiative impact.

Recent eruption events have led to high amounts of aerosols in the lower stratosphere. On 8 August 2008, the Kasatochi volcano $\left(52^{\circ} \mathrm{N}, 175^{\circ} \mathrm{W}\right)$ in the Aleutian Islands in southwestern Alaska injected an estimated amount of 1.5$2.5 \mathrm{Tg}$ of $\mathrm{SO}_{2}$ into the upper troposphere and lower stratosphere (UTLS) (Bourassa et al., 2010; Kravitz et al., 2010; Krotkov et al., 2010). In June 2009 the Sarychev volcano $\left(48.1^{\circ} \mathrm{N}, 153.2^{\circ} \mathrm{E}\right)$ located in the Kuril Islands to the northeast of Japan erupted explosively, injecting ash and an estimated $\sim 1 \mathrm{Tg}$ of sulphur dioxide into the UTLS (Clarisse et al., 2012). At the time, these two eruptions were estimated to rank in the top 10 perturbations to the stratospheric aerosol optical depth (AOD) in the past $50 \mathrm{yr}$ (Haywood et al., 2010). More recently, the Nabro volcano $\left(13^{\circ} \mathrm{N}, 41^{\circ} \mathrm{E}\right)$ in Eritrea emitted 1.3 Tg (Bourassa et al., 2012a) of $\mathrm{SO}_{2}$, with the subsequent formation of aerosols up to $\sim 19 \mathrm{~km}$ (Sawamura et al., 2012). These three volcanic events have been among the largest ones since the Mt Pinatubo eruption in June 1991 which, for comparison, injected up to $20 \mathrm{Tg}$ of $\mathrm{SO}_{2}$ into the stratosphere (Bluth et al., 1992).

This paper is focused on the Sarychev eruption with the aim to characterize the physical properties of the produced stratospheric aerosols and their variability, using balloon-borne observations obtained in the framework of the StraPolÉTé (French acronym for "Stratosphère Polaire en ÉTé") project integrated to the International Polar Year, satellite data and ground-based lidar measurements. The balloon campaign took place close to Kiruna, Sweden $\left(67.5^{\circ} \mathrm{N}\right.$, $21.0^{\circ} \mathrm{E}$ ), from 2 August 2009 to 7 September 2009 with eight balloon flights. The enhancement of the optical depth caused by the Sarychev eruption lasted 8 months, returning to a pre-Sarychev eruption value in February 2010 (Doeringer et al., 2012). Data from the AEROWAVE (AEROsol WAter Vapor and Electricity) campaign conducted in spring 2010 over Kiruna have been used to quantify the aerosol concentrations in recovered "background conditions". Outputs from the HadGEM2 climate model have been used for comparisons with the aerosol physical properties derived from the balloon-borne observations and to investigate the role of stratospheric dynamics on the aerosol spatial distribution over the sounded period.

The paper is organized as follows. Section 2 briefly describes the instruments and the model. Section 3 characterizes the geographic distribution of $\mathrm{SO}_{2}$ over polar regions. Section 4 shows the distribution of sulphate aerosols over Europe from satellite data. Section 5 describes the influence of the atmospheric dynamics on the polar aerosol layer. The physical properties of the sulphate aerosols over the Kiruna region deduced from balloon-borne and satellite measurements are shown in Sect. 6. Finally, a discussion of the results is provided.

\section{Instrumentation and model descriptions}

\subsection{Balloon-borne and ground-based observations}

The Stratospheric and Tropospheric Aerosol Counter (STAC) is an aerosol optical counter dedicated to the measurements of aerosol concentrations in various size classes (Renard et al., 2008). The measurements of the light scattered by aerosols that cross the laser beam are performed at a scattering angle of $70^{\circ}$. Since 2008 , the number of available size classes has been increased from 7 to 14 over the 0.4-5 $\mu \mathrm{m}$ diameter size range (Renard et al., 2010). The counting uncertainty is obtained from the statistical probability given by Poisson counting statistics (Willeke and Liu, 1976). This uncertainty, defined as the relative standard deviation, is $60 \%$ for aerosol concentrations of $10^{-3} \mathrm{~cm}^{-3}$, $20 \%$ for $10^{-2} \mathrm{~cm}^{-3}$, and $6 \%$ for concentrations higher than $10^{-1} \mathrm{~cm}^{-3}$. However, laboratory comparisons between two 
copies of the STAC aerosol counters using identical aerosols have shown differences of $\pm 10 \%$ for concentrations higher than $10^{-2} \mathrm{~cm}^{-3}$. From these results, we define a measurement precision limited to $\pm 10 \%$. Note that comparisons with the aerosol concentrations measured by the University of Wyoming optical particle counter (Deshler et al., 2003) have shown consistent results between both instruments (Renard et al., 2002). STAC is calibrated in order to provide size distributions of non-absorbing liquid aerosols. For stratospheric measurements in presence of solid and/or absorbing aerosols (Renard et al., 2010) characterized by a non-negligible imaginary part of the refractive index, the light scattered at the $70^{\circ}$ scattering angle is weaker than for liquid particles. The concentration in a given size class can be underestimated because the contribution of these solid/absorbing aerosols could be attributed to lower size classes. In this case, the size distribution becomes inaccurate. For this reason, the altitude has been limited to the $8-19 \mathrm{~km}$ range to focus this study on layers with the predominant presence of liquid sulphate aerosols resulting from the Sarychev eruption. A STAC aerosol counter was on board the eight balloons launched from 2 August to 7 September 2009.

Contrary to these in situ measurements, the following observations are remote soundings. The Micro Radiomètre Ballon (MicroRADIBAL) is a photopolarimeter developed by the Laboratoire d'Optique Atmosphérique (Brogniez et al., 2003). The measurements are performed in five channels centred in the near infrared at 740, 865, 1000, 1290, and $1625 \mathrm{~nm}$. The radiometer measures the sunlight scattered by the atmosphere, and an absolute calibration in the laboratory enables radiance and degree of linear polarization of the scattered sunlight to be obtained. The rotation of the gondola around its vertical axis provides observations in various directions in a quasi-horizontal plane. Diagrams of the normalized radiance and of the polarized radiance versus scattering angle are modelled for a mixing of gas and particles. In the model, the particle size distributions are assumed to be lognormal (LND). LND parameters are adjusted to match the measurement diagrams. MicroRADIBAL is more sensitive to particles with radii larger than $0.05 \mu \mathrm{m}$. This characteristic could explain a degraded estimation of the small particles. The MicroRADIBAL observations were conducted on 18 August 2009 between 15:30 and 19:15 UTC.

Stratospheric aerosol extinction profiles were measured by the Spectroscopie d'Absorption Lunaire pour l'Observation des Minoritaires Ozone et NOx (SALOMON) balloon-borne instrument. On 25 August 2009, we flew a successor of the former SALOMON instrument, which was described by Renard et al. (2000). The new version of the instrument is able to either use the Moon or the Sun as light source. The data presented in this study have been obtained during sunset between 17:00 and 19:45 UTC using an SAOZ-type spectrometer (Pommereau and Piquard, 1994) connected to the sun tracker. The aerosol optical depth is retrieved typically using the differential optical absorption spectrometry (DOAS) method. The ozone and $\mathrm{NO}_{2}$ contributions are removed over the spectral domain and the spectral residuum is fitted using a third-order polynomial. Aerosol extinction is retrieved after spatial inversion of the recorded optical depths. The data reduction method used in this study is described in detail by Berthet et al. (2002).

The Haute-Provence Observatory (OHP, $43.93^{\circ} \mathrm{N}$, $\left.5.71^{\circ} \mathrm{E}\right)$ is one of the Network for the Detection of Atmospheric Composition Changes' (NDACC) northern mid-latitude stations. It is equipped with a stratospheric ozone lidar, which uses the differential absorption lidar (DIAL) technique to obtain measurements of the stratospheric ozone vertical distribution. This technique requires the emission of two laser wavelengths with different ozone absorption cross sections. In the case of the OHP lidar the absorbed radiation is emitted at $308 \mathrm{~nm}$ and the reference line (non-absorbed wavelength) at $355 \mathrm{~nm}$. Under high aerosol loading conditions (e.g. volcanic plume), aerosols perturb the ozone spectrum locally. In applying the Klett-Fernald inversion technique (e.g. Klett, 1981) to the non-absorbed wavelength signal, backscatter coefficients and backscatter ratios at $355 \mathrm{~nm}$ are retrieved. Backscatter ratios measured from June to mid-November were used to characterize the Sarychev plume over southern France. The extinction to backscatter ratio required for the Klett-Fernald method was derived from aerosol size distribution measurements by balloon-borne aerosol optical counter at Laramie, Wyoming (USA) (Deshler et al., 2003). The mean value of this ratio for the period of interest is $53 \pm 6 \mathrm{sr}$ between 10 and $25 \mathrm{~km}$. Further details about the instrument can be found in Godin-Beekmann et al. (2003).

\subsection{Satellite-borne observations}

The Infrared Atmospheric Sounding Interferometer (IASI) is a nadir-looking remote sounder on board the Meteorological Operational satellite (MetOp-A) launched in October 2006 into a Sun-synchronous polar orbit. IASI provides global coverage of the thermal outgoing radiation of the Earth in the $645-2760 \mathrm{~cm}^{-1}$ spectral range. The footprint is $12 \mathrm{~km}$ in diameter at nadir and the swath width is around $2200 \mathrm{~km}$. Its spatial coverage makes the instrument suitable for monitoring a range of atmospheric species (Clerbaux et al., 2009), in particular for detecting and tracking volcanic $\mathrm{SO}_{2}$ clouds (Clarisse et al., 2008). The $\mathrm{SO}_{2}$ data version 2.004 (Clarisse et al., 2012) are interpolated on a $0.25 \times 0.25$ lat-long grid twice a day, corresponding to 09:30 and 21:30 LST.

The Cloud-Aerosol Lidar and Infrared Pathfinder Satellite Observation (CALIPSO) satellite was launched in April 2006 into a Sun-synchronous polar orbit. The Cloud-Aerosol Lidar with Orthogonal Polarization (CALIOP) is an instrument on board CALIPSO (Winker et al., 2007). CALIOP is a two-wavelength polarization lidar (532 and $1064 \mathrm{~nm}$ ) that provides attenuated backscatter vertical profiles from the surface to $40 \mathrm{~km}$ along the satellite track with varying 
vertical (30-300 m) and horizontal (300-5000 m) resolutions depending on the altitude. In the troposphere, the detection limit of the aerosol attenuated backscatter signal is about $3.10^{-4} \mathrm{~km}^{-1} \mathrm{sr}^{-1}$ (Winker et al., 2009). The level 2 product differentiates between clouds and aerosols (Liu et al., 2009). In this study, the $532 \mathrm{~nm}$ extinction coefficient from the standard CALIPSO $5 \mathrm{~km}$ aerosol and cloud layer version 3 products is used.

The Optical Spectrograph and Infrared Imaging System (OSIRIS) instrument (Llewellyn et al., 2004) on the Odin spacecraft measures the vertical profile of atmospheric limb radiance spectra in the $274-810 \mathrm{~nm}$ wavelength range. The satellite was launched on 20 February 2001 into a Sunsynchronous polar orbit and continues full operation to the present day. These measurements are used to retrieve aerosol extinction profiles throughout the stratosphere approximately every $5^{\circ}(\sim 550 \mathrm{~km})$ along the satellite track with a vertical resolution of approximately $2 \mathrm{~km}$ from around 10 to $35 \mathrm{~km}$. The newly validated version 5 (V5) of the OSIRIS aerosol extinction retrievals at $750 \mathrm{~nm}$ (Bourassa et al., 2012b) is used in this study. The estimated error of V5 extinction is of $10-15 \%$ in the mid-stratosphere (Bourassa et al., 2012c).

\subsection{Model descriptions}

We used the atmosphere-only version of HadGEM2, the Hadley Centre Global Environment Model version 2 (Collins et al., 2008). The atmosphere horizontal resolution is of $1.25^{\circ}$ latitude by $1.875^{\circ}$ longitude. The model used here has 60 vertical levels with the model top at around $80 \mathrm{~km}$, with 32 levels in the stratosphere and 28 in the troposphere, 12 of which are in the boundary layer. The HadGEM2 sulphate aerosol scheme is described by Jones et al. (2001) and Bellouin et al. (2007). Oxidation of $\mathrm{SO}_{2}$ leads to the formation of accumulation sulphate aerosol mode (see Eq. (2) in Sect. 6, LND parameters at $0 \%$ relative humidity: median radius $r_{\mathrm{m}}=0.095 \mu \mathrm{m}$, geometric standard deviation $\sigma=1.4$, Jones et al., 2001). The model accumulation mode size distribution is a reasonable representation of the optically dominant mode of the Pinatubo stratospheric aerosol (Deshler et al., 2003; Carslaw and Kärcher, 2006). The sulphur scheme was originally designed to investigate tropospheric aerosols where $\mathrm{H}_{2} \mathrm{SO}_{4}$ is assumed to be fully neutralized by $\mathrm{NH}_{3}$ and assumed to exist as $\left(\mathrm{NH}_{4}\right)_{2} \mathrm{SO}_{4}$. This assumption has been removed so that sulphate is treated as $\mathrm{H}_{2} \mathrm{SO}_{4}$ throughout (Jones et al., 2010).

The HadGEM2 atmosphere-only simulations are constrained by observed sea surface temperatures and the wind fields and potential temperature are nudged to European Centre for Medium-range Weather Forecasts (ECMWF) reanalyses (Haywood et al., 2010). Simulations are performed with and without $\mathrm{SO}_{2}$ emissions from the Sarychev eruption, and the difference between the simulations allows assessment of the impact of the Sarychev eruption.
However, because the model is only nudged to the ECMWF reanalyses rather than overwritten by them, the meteorological conditions are not precisely identical, especially near the surface where no nudging is applied directly. Due to this nudging in the free troposphere and stratosphere and the use of prescribed sea surface temperatures, a part of the climatic response is not developed in the model. However, the radiative heating calculated from volcanic aerosols is used to change the temperatures and allow some of the climate response. The simulation of the Sarychev eruption has been initiated for the period 00:00 UTC on 15 June through to 24:00 UTC on 16 June. From analysis of IASI data (prior to the newly released 2.004 version), a total of $1.2 \mathrm{Tg} \mathrm{SO}_{2}$ (with an error estimate of $\pm 0.2 \mathrm{Tg}$ ) was injected into the model UTLS between approximately 11 and $15 \mathrm{~km}$ at a constant rate of $0.025 \mathrm{Tg} \mathrm{SO}_{2} \mathrm{hr}^{-1}$. More details of the simulation used in this study can be found in Haywood et al. (2010).

We also used the MIMOSA (French acronym for Modélisation Isentrope du transport Méso-échelle de l'Ozone Stratosphèrique par Advection) high-resolution advection model of potential vorticity (PV) to evaluate the isentropic transport in the polar region from ERA-Interim wind, pressure, and temperature reanalysis. MIMOSA initially computes the PV field at a resolution of $1.125^{\circ}$ in latitude and longitude vertically interpolated on an isentropic surface. This field is then interpolated on an lat-long grid centred on the North Pole with a horizontal resolution of $37 \mathrm{k} \mathrm{m} \times 37 \mathrm{~km}$ (three grid points / degree) and advected with a time step of $1 \mathrm{~h}$. To preserve the homogeneity of the field, a regridding of the PV field on the original grid is calculated every $6 \mathrm{~h}$. The information on diabatic changes in the PV field at large scales can be extracted from the ERA-Interim fields. For the MIMOSA model this is done by applying to the advected field a relaxation towards the ERA-Interim PV field calculations with a time constant of 10 days. This technique allows continuous running of MIMOSA over periods of several months in order to follow the evolution of dynamical barriers and fine-scale structures such as vortex remnants and tropical intrusions (Hauchecorne et al., 2002).

\section{Geographic distribution of $\mathrm{SO}_{2}$}

After $33 \mathrm{yr}$ of inactivity, the Sarychev volcano erupted violently on 11 June 2009 and several explosive events followed over a 5-day period. The first two $\mathrm{SO}_{2}$ plumes from Sarychev were detected on 11 June 2009 and many more small plumes followed until 15 June. On 15 and 16 June two large plumes were detected. The altitude of the individual volcanic clouds were reported by the Tokyo VAAC (Volcanic Ash Advisory Centres) and corresponded to 4-11 km on 11-13 June and to $10-16 \mathrm{~km}$ on $15-16$ June with a maximum of $20 \mathrm{~km}$ on 14 June (Rybin et al., 2011). The IASI data used in this study differ from the data used in the HadGEM2 simulation essentially by the maximum value, $0.9 \mathrm{Tg}$ on $15-16$ June (black 
line Fig. 1), which is retrieved from the new IASI version 2.004. This version is presumed to be more accurate, with smoother time series (Clarisse et al., 2012). However, we chose to maintain the $1.2 \mathrm{Tg}$ total value used by Haywood et al. (2010) because, taking into account the Sarychev eruption as a whole (between 11 and 16 June 2009), the total amount of $\mathrm{SO}_{2}$ released in the stratosphere is likely to be higher than the maximum observed value of $0.9 \mathrm{Tg}$ (Clarisse et al., 2012) if we consider the smaller injections (of about $0.1 \mathrm{Tg}$ more difficult to detect by IASI), prior to the main eruption. Then the $1.2 \mathrm{Tg}$ value can be considered as a maximum contribution of the Sarychev eruption.

The maximum in the $\mathrm{SO}_{2}$ IASI data is reached on 16 June with a following e-folding time of $\sim 11$ days. Haywood et al. (2010) estimated that the detection limit of IASI of 0.30.5 Dobson units (1 Dobson unit (DU) is equivalent to approximately $0.0285 \mathrm{~g} \mathrm{SO}_{2} \mathrm{~m}^{-2}$ ) could lead to the reduction of the e-folding time by around $50 \%$. In comparison, the HadGEM2 e-folding time is 13-14 days (Haywood et al., 2010). This gap in the e-folding time could be attributed to a slower oxidation of $\mathrm{SO}_{2}$ or overly dispersive dynamics in the model. The blue dashed line in Fig. 1 shows the $\mathrm{SO}_{2}$ total mass in $\mathrm{Gg}$ over the Kiruna region. The distribution within this $\pm 10^{\circ}$ lat-long box is controlled by the total emission, the oxidation, and by the long-range transport of $\mathrm{SO}_{2}$ in the lower stratosphere. At first, the volcanic clouds are transported by the westerly winds around $12 \mathrm{~km}$ and $40^{\circ}$ latitude. This jet rapidly transports the air masses across the Pacific. Subsequently, Rossby wave-breaking events perturb this long-range transport by creating meridional excursions of air. From 18 June, complex plumes are observed over North America which can be moved poleward and upward via an isentropic transport characteristic of the poleward branch of the Brewer-Dobson circulation (Holton, 2004). Thus, within two weeks after the eruption the $\mathrm{SO}_{2}$ clouds are present over the whole polar region, North America and Europe. This complex transport is most clearly seen by examining the evolution of Ertel's potential vorticity (PV) on isentropic surfaces. The spatial evolution of the $\mathrm{SO}_{2}$ distribution well matches the $380 \mathrm{~K}$ isentropic surface maps computed by the MIMOSA model (Hauchecorne et al., 2002) and available on the Ether website at http://ether.ipsl.jussieu.fr.

Figure 2 shows the evolution of the $\mathrm{SO}_{2}$ cloud location from 16 June to 16 July 2009 as observed by IASI. The 1516 June Sarychev plume rapidly reaches the west of Canada on 17 June, crosses North America a few days after, and passes over northern Sweden on 25 June (day 176), namely two weeks after the Sarychev eruption. The temporal evolution over Kiruna region is then characterized by two major peaks on 28 June (day 179) and 1 July (day 182), and two minor peaks on 6 (day 187) and 9 (day 190) July (blue dashed line, Fig. 1). These peaks are explained by volcanic plumes coming from the northwest and southwest through isentropic transport. Figure 2 also tends to show that the highest $\mathrm{SO}_{2}$ concentrations are generally located at latitudes

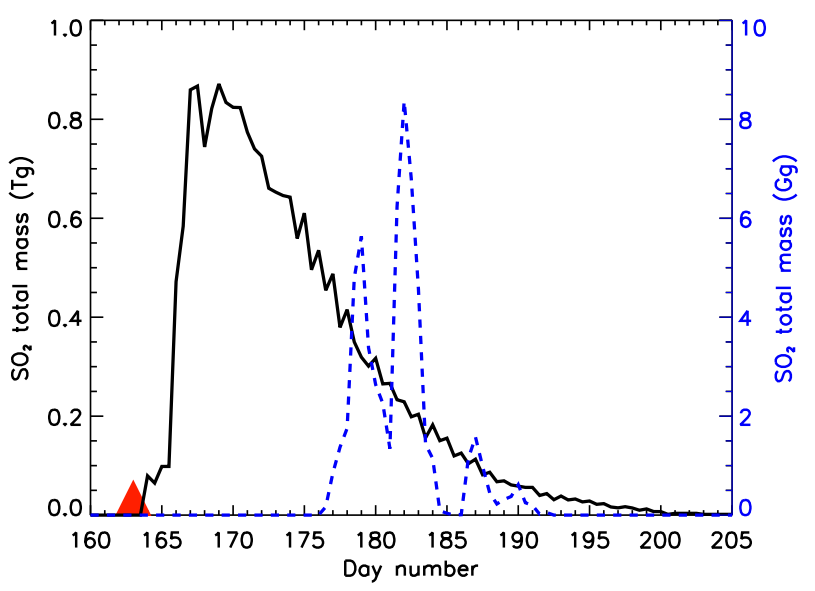

Fig. 1. Temporal evolution of the $\mathrm{SO}_{2}$ total mass over the Kiruna region (blue dashed line, $\pm 10^{\circ}$ lat-long box, in $\mathrm{Gg}$ ) and Northern Hemisphere (black line, in Tg) observed by the IASI instrument on board the METOP-A satellite from 9 June to 24 July 2009. The Sarychev eruption is symbolized by the red triangle.

north of the eruption, but southern transport could exist in relation to different meteorological situations. For example, the high $\mathrm{SO}_{2}$ concentrations over the North Atlantic during the period from 26 June (day 177) to 2 July (day 183) are associated with the development of an upper trough which displaces the volcanic plumes down to $20-30^{\circ} \mathrm{N}$ latitudes.

Figure 3 shows the $\mathrm{SO}_{2}$ vertical distribution from the surface to the lower stratosphere (top) and the vertically integrated $\mathrm{SO}_{2}$ columns (bottom) over Kiruna simulated by the HadGEM2 model. The variability over Kiruna is well represented with a first Sarychev plume over Kiruna on 24 June (day 175), followed by large enhancements between 28 June (day 179) and 2 July (day 183). The large enhancements which spread over 9-15 km (on 28 June, day 179) and 10$17 \mathrm{~km}$ (on 1 July, day 182) altitude range match the two $\mathrm{SO}_{2}$ peaks observed by IASI over Kiruna (Fig. 1) with difference within $\pm 2 \mathrm{Gg}$ (Fig. 3). The two minor enhancements shown in the IASI observations (Fig. 1) are also present in the model (Fig. 3) from 6 July (day 187) with values 0.5 and $1.3 \mathrm{Gg}$ higher, respectively. The good agreement between the IASI data and the model calculations gives confidence in the simulation of the multi-scale transport and of the $\mathrm{SO}_{2}$ treatments included in the HadGEM2 model.

\section{Distribution of aerosols over Europe}

Figure 4 shows the temporal evolution of the OSIRIS individual extinction profiles (top) and optical depth (bottom) of aerosols over the Kiruna region $\left( \pm 10^{\circ}\right.$ lat-long), between 10 and $30 \mathrm{~km}$, for the $2007-2010$ period. The black squares represent the altitude of the $380 \mathrm{~K}$ level reflecting the upper boundary of the lowermost stratosphere at mid-latitudes and high latitudes (Bourassa et al., 2010). Data below this 


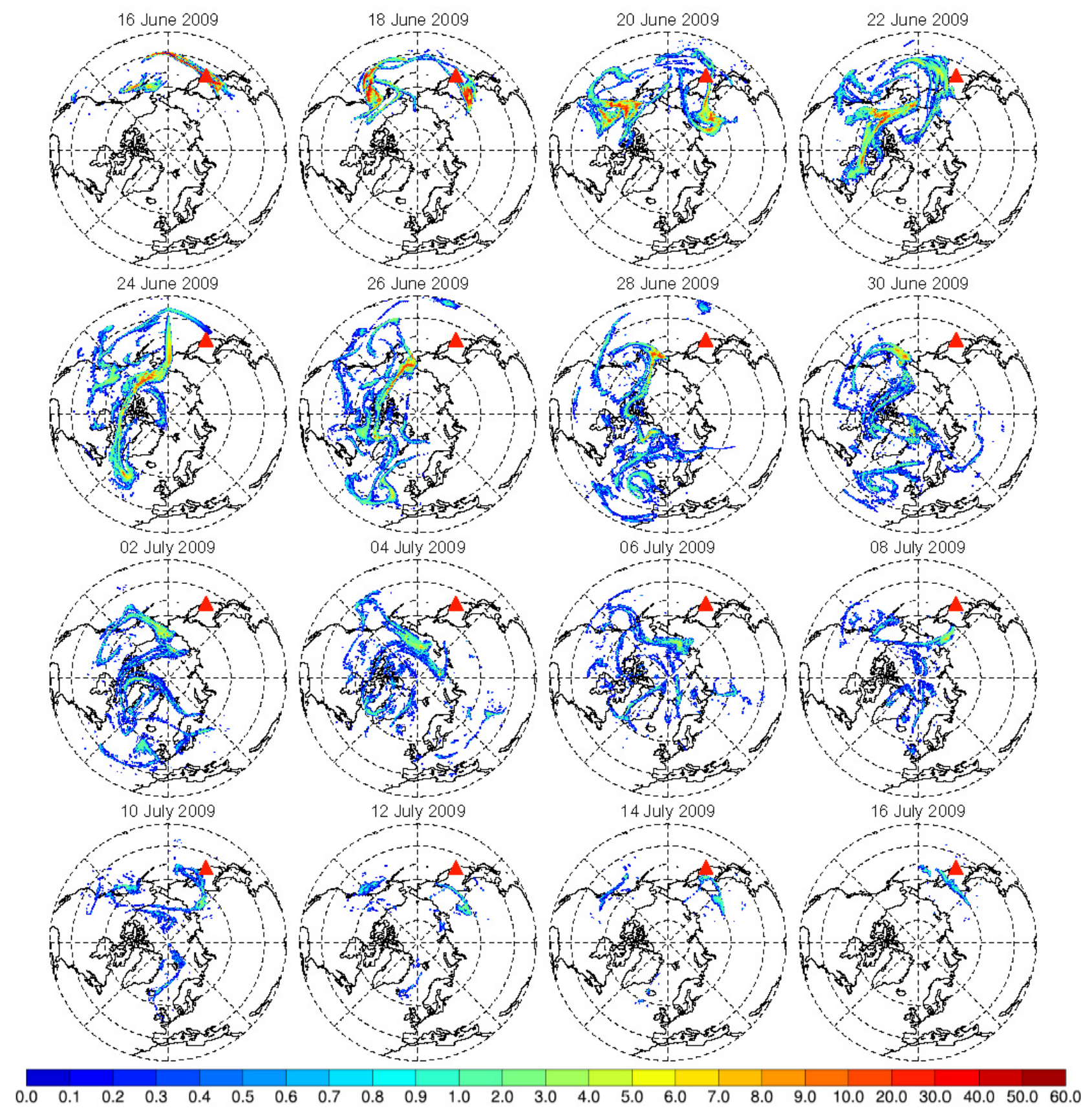

Fig. 2. Evolution of plumes of $\mathrm{SO}_{2}$ over the Northern Hemisphere observed by the IASI instrument on board the METOP-A satellite in Dobson units (DU) for the 16 June-16 July 2009 period. The Sarychev volcano is indicated by the red triangle.

altitude could be contaminated by solid particles such as cirrus or dust. The two red triangles in 2008 and 2009 indicate the Kasatochi and Sarychev eruptions, respectively. There is no observation during the November-February period corresponding to the unilluminated polar wintertime. The main feature revealed by Fig. 4 is the higher aerosol loading over Kiruna after the Sarychev eruption compared to the Kasatochi period. These results are also consistent with the global aerosol optical depth analyses from OSIRIS (Haywood et al., 2010). This difference highlights the shorter residence time of the stratospheric aerosol produced by the Kasatochi eruption, possibly explained by an initial lower height of injection which facilitates the aerosol removal. The Sarychev and Kasatochi plumes extend up to around $18 \mathrm{~km}$ and $13 \mathrm{~km}$, respectively. A secondary Kasatochi plume is present in the September-October period around $14-18 \mathrm{~km}$. 


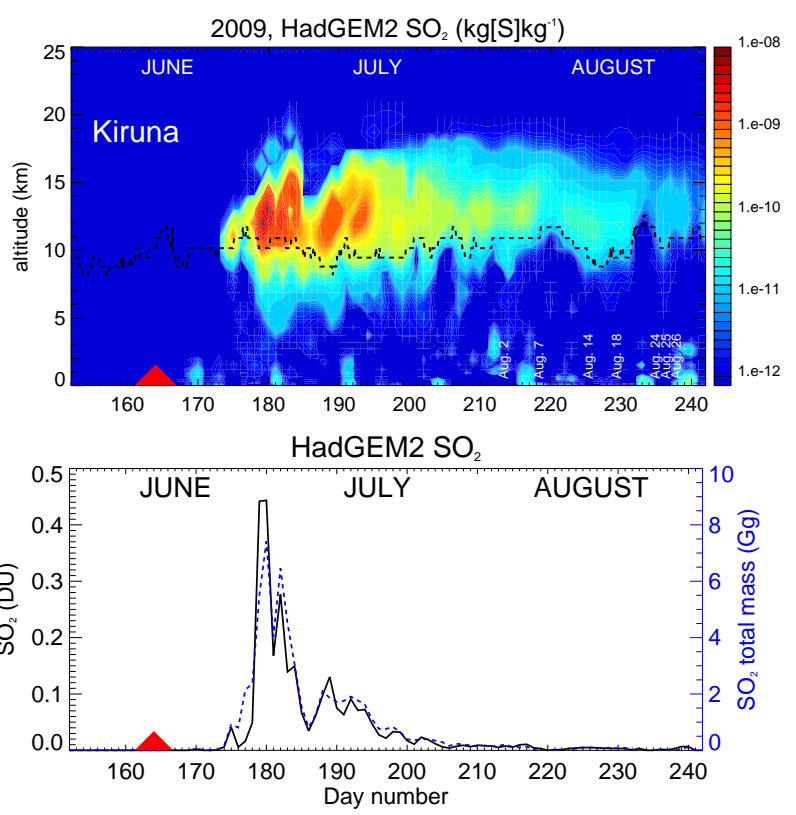

Fig. 3. $\mathrm{SO}_{2}$ daily evolution over Kiruna from June to August 2009 modelled by the HadGEM2 climate model from the surface to $25 \mathrm{~km}$ (top) and in vertically integrated columns (bottom) over Kiruna in DU (black line) and over a $\pm 10^{\circ}$ lat-long box centred over Kiruna in Gg (blue dashed line). The dates of the STAC flights in August are indicated in white in the upper panel. The black dashed line is the model thermal tropopause. The Sarychev eruption is symbolized by the red triangle.

Large emission maxima and smaller emissions up to $20 \mathrm{~km}$ from the Kasatochi eruption are also present in the GOME2, OMI and AIRS satellite data (Kristiansen et al., 2010). The Sarychev plume shows maximum values in late July with an AOD peak of about 0.02. The e-folding time is approximately 80 days. Background conditions completely recovered in early March 2010 at the end of the polar winter. In early spring the AOD level returned to the 0.0035 preeruption value already observed before the Kasatochi eruption. The impact of the Sarychev eruption over Kiruna can be estimated by an enhancement factor of the AOD equal to 6 , which is about twice the enhancement resulting from the Kasatochi eruption. These results are in agreement with the $70-80^{\circ}$ latitude range analysis of the OSIRIS data reported by Kravitz et al. (2011).

The top of Fig. 5 shows the CALIOP time series of the Northern Hemisphere (up to $82^{\circ} \mathrm{N}$ ) daily extinctions at $532 \mathrm{~nm}$ averaged over the $8-20 \mathrm{~km}$ and $15^{\circ} \mathrm{W}-45^{\circ} \mathrm{E}$ altitude-longitude box. The bottom of Fig. 5 shows the CALIOP time series of the daily extinction profiles at $532 \mathrm{~nm}$ averaged over Europe $\left(40-80^{\circ} \mathrm{N}, 15^{\circ} \mathrm{W}-45^{\circ} \mathrm{E}\right)$. Both time series cover the 2007-2010 period. These figures confirm the greater temporal and vertical extent of the Sarychev plume over Europe compared to the Kasatochi plume. The Sarychev plume arrived over Europe on the last days of June and remained between 10 and $18 \mathrm{~km}$ until August without noticeable altitude decrease. From mid-August to mid-October the plume vertically descended from $10-18 \mathrm{~km}$ to $7-13 \mathrm{~km}$. From mid-October to late November the plume progressively vanished and the lowermost stratosphere seemed to have returned to background conditions in December. The e-folding time deduced from CALIOP is roughly in agreement with the 80 days OSIRIS e-folding time. For comparison, the CALIOP data show that the Kasatochi plume arrived over Europe in mid-August between 8 and $13 \mathrm{~km}$ before vertically decreasing to the $6-9 \mathrm{~km}$ altitude range in early November, when the aerosols returned to background conditions. Thus, the residence time of the volcanic plumes over Europe is about 2.5 and 5.5 months for the Kasatochi and Sarychev eruptions, respectively. O'Neill et al. (2012) have suggested a consistent e-folding time of about 90 days from OSIRIS data near the Eureka high-latitude site (Nunavut, Canada, $80.05^{\circ} \mathrm{N}, 86.42^{\circ} \mathrm{W}$ ).

The high values of extinction in the $17-27 \mathrm{~km}$ altitude range from December to February are caused by polar stratospheric clouds and are consequently irrelevant for this study. An unexpected "aerosol hole" depending of the latitudes is present north of $60^{\circ} \mathrm{N}$ from August to September 2009. This surprising structure has already been detected by O'Neill et al. (2012) and can be explained by noisier data during daylight observations. In this case, an artificial "aerosol hole" can appear as soon as the aerosol loading is not above the detection threshold for daytime measurements during the permanently illuminated polar summer. This "aerosol hole" tends to disappear at the end of the polar summer. However it is clear from Fig. 5 that during the illuminated polar summer, stratospheric plumes can be detected by CALIOP close to the eruptions when the aerosol amounts are above the detection threshold.

On the last days of June the volcanic plume reached the coasts of North Africa corresponding to $35^{\circ}$ latitude (top Fig. 5). This southward extent gives the opportunity to monitor the aerosol plume using observatories involved in networks as EARLINET (European Aerosol Research LIdar NETwork) or NDACC. D'Amico et al. (2010) using the two multi-wavelength Raman lidars located at Tito Scalo, Potenza, Italy $\left(40^{\circ} 36^{\prime} \mathrm{N}, 15^{\circ} 44^{\prime} \mathrm{E}\right)$, have observed aerosol layers during the summer 2009 in the UTLS and up to a maximum height of $24 \mathrm{~km}$. Lidar measurements detected the Sarychev plume over Tito Scalo after 25 June and highlight a strong layer between 12 and $13.5 \mathrm{~km}$ on $26-27$ June. A new aerosol layer is visible on 2 July between 14 and $15.5 \mathrm{~km}$. From this date onwards, lidar observations show a decrease of the aerosol loading in the lowermost stratosphere over Tito Scalo. Figure 6 shows another example of time series of the backscattering ratio at $355 \mathrm{~nm}$ obtained by the DIAL instrument located at the OHP station from 1 June to 10 November 2009 between 8 and $25 \mathrm{~km}$. The backscatter ratio is defined as the function $\frac{\beta_{\text {molecules }}+\beta_{\text {particles }}}{\beta_{\text {molecules }}}$, where $\beta$ represents either molecular or aerosol backscatter, so any values less than 

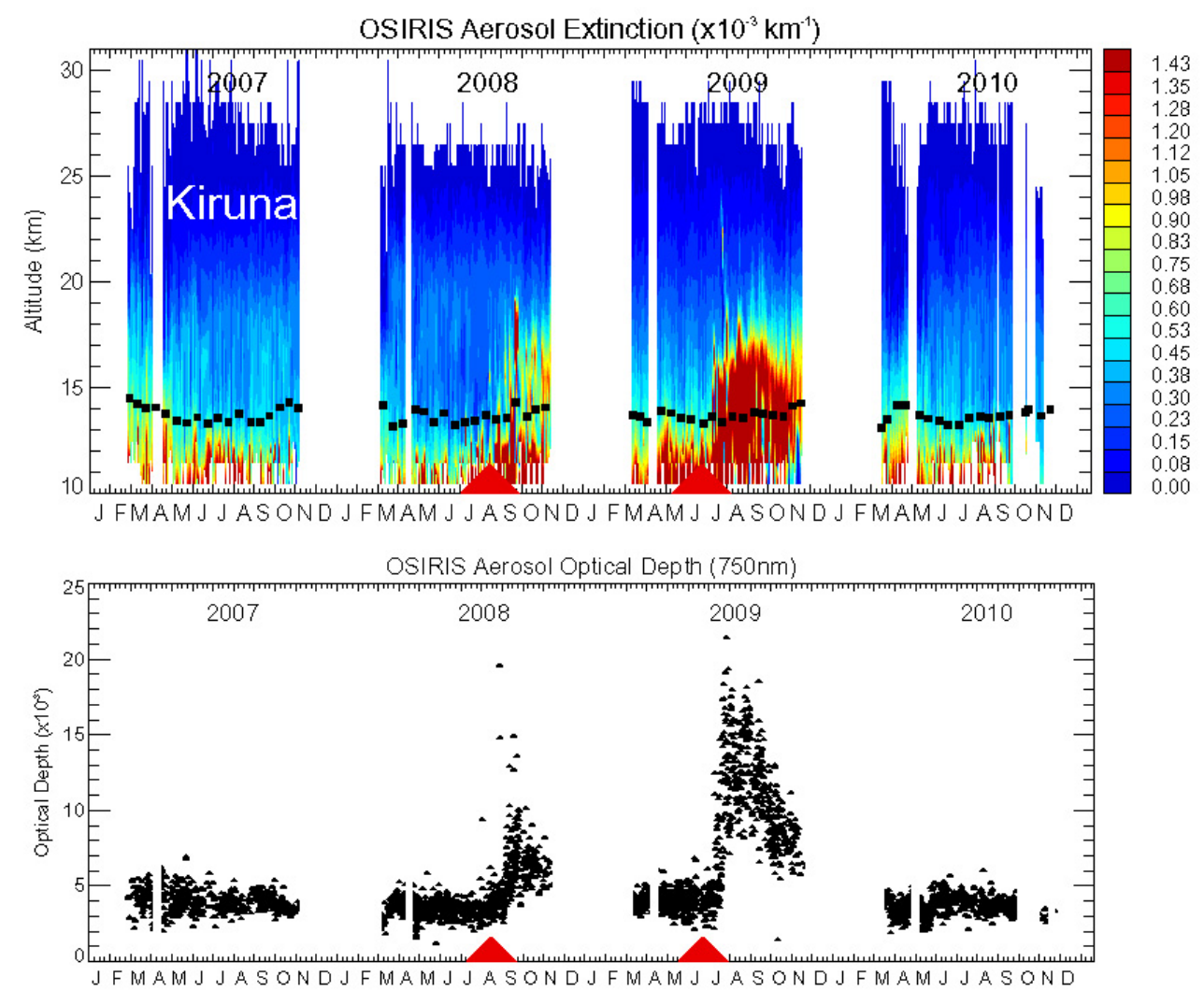

Fig. 4. Evolution of the extinction coefficient (top) and AOD (bottom) between 10 and $30 \mathrm{~km}$ measured by the OSIRIS instrument on board the ODIN satellite over Kiruna region $\left( \pm 10^{\circ}\right.$ lat-long box $)$ during the $2007-2010$ period. The $380 \mathrm{~K}$ potential temperature level is indicated by the black squares. The Kasatochi (2008) and the Sarychev (2009) eruptions are symbolized by the red triangles.

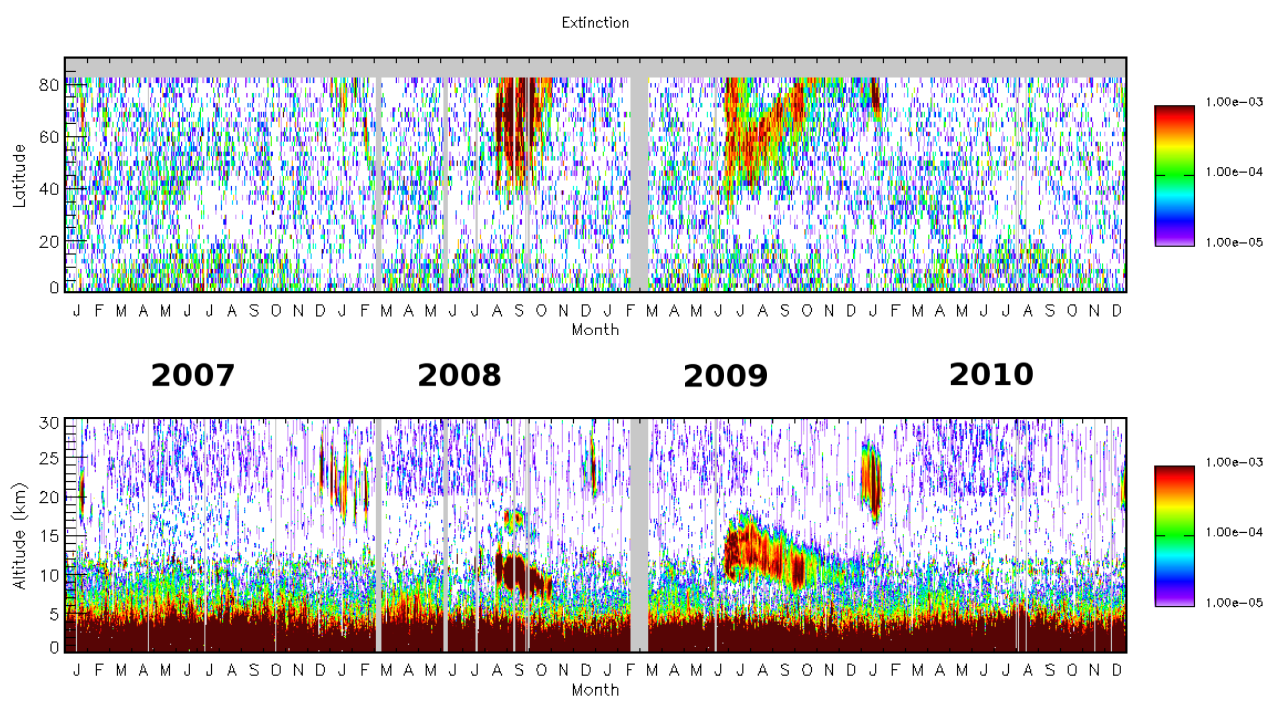

Fig. 5. Daily mean aerosol extinction coefficient in $\mathrm{km}^{-1}$ measured by the CALIOP lidar on board the CALIPSO satellite during the 20072010 period. Top: averaged values between 8 and $20 \mathrm{~km}$ and for the longitudes between $15^{\circ} \mathrm{W}$ and $45^{\circ}$ E. Bottom: average profiles over Europe $\left(40-80^{\circ} \mathrm{N}, 15^{\circ} \mathrm{W}-45^{\circ} \mathrm{E}\right)$. Grey bars represent days without data. 


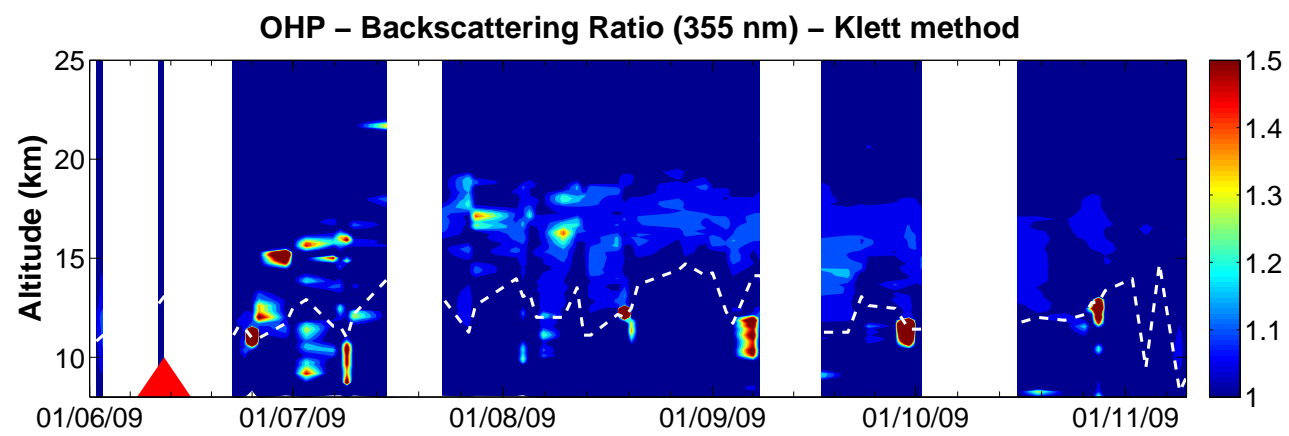

Fig. 6. Aerosol backscatter ratio observed with the $355 \mathrm{~nm}$ OHP lidar (Observatoire de Haute Provence, France) during the 1 June $2009-10$ November 2009 period. The dashed white line is the thermal tropopause. The Sarychev eruption is symbolized by the red triangle.

1 are spurious and are likely due to instrumental noise. The dashed line represents the thermal tropopause height derived from collocated balloon soundings. The large white bands show periods without observations. The Sarychev plume was detected over the OHP station on 24-25 June between 12.5 and $13.5 \mathrm{~km}$, followed by a more pronounced aerosol layer between 13 and $16.5 \mathrm{~km}$ until 12 July, when data are missing. From mid-July to around 20 October, the plume extends from the tropopause up to $\sim 19.5 \mathrm{~km}$ with two maximum peaks on 2 and 8 August at 17 and $16.2 \mathrm{~km}$, respectively. Finally, the plume becomes undetectable by the lidar during the last days of October. Figure 6 seems to show that variations in the lower part of the Sarychev plume are completely associated with variations in the tropopause height. Upper tropospheric troughs which control tropopause height tend to displace the plume downward. The plume observed by the OHP lidar seems to extend about $1 \mathrm{~km}$ higher than the maximum altitude estimated from the satellite data and corresponds to approximately the same e-folding time (80 days).

\section{Modelling the aerosol plume}

The HadGEM 2 model has been used to investigate the role of dynamics on the structure of the aerosol layer. Figure 7 shows the Sarychev plume (in $\mathrm{kg}[\mathrm{S}] \mathrm{kg}^{-1}$ air) simulated over Kiruna from June to late August 2009 (top figure) and the associated AOD at $550 \mathrm{~nm}$ and $750 \mathrm{~nm}$ (bottom figure). The dashed line on top of Fig. 7 represents the model thermal tropopause height and the red triangle highlights the Sarychev eruption on 11 June. The red line and crosses on bottom of Fig. 7 are simulated and lidar AOD over OHP station at $550 \mathrm{~nm}$, respectively.

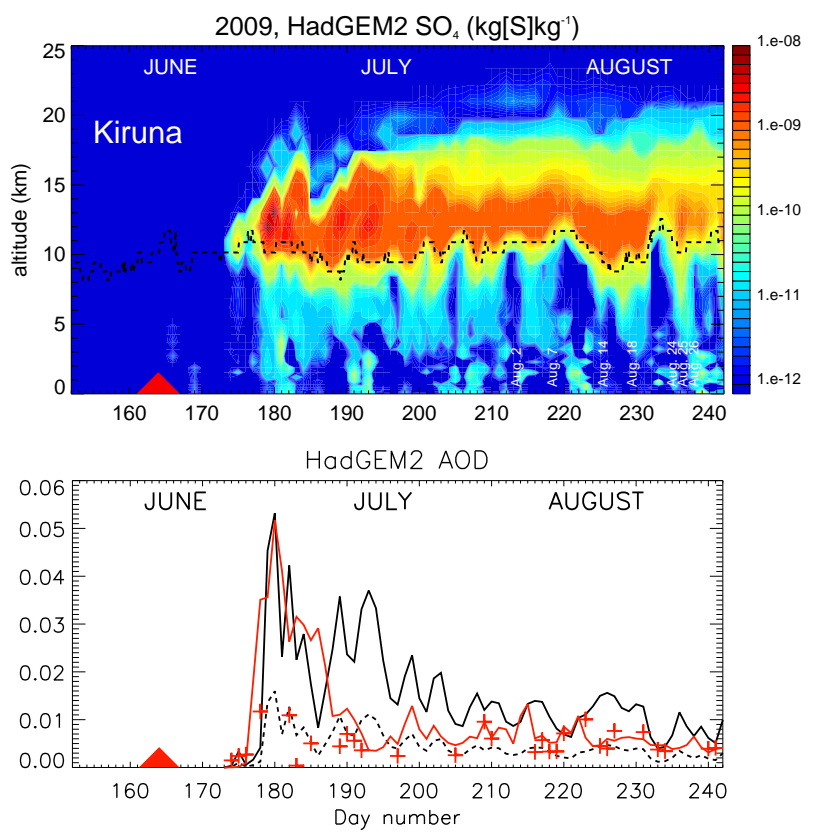

Fig. 7. Evolution from June to August 2009: $\mathrm{SO}_{4}$ (top) and $\mathrm{AOD}$ at $550 \mathrm{~nm}$ (bottom black line) and $750 \mathrm{~nm}$ (bottom black dashed line) over Kiruna modelled by the HadGEM2 climate model. Evolution from June to August 2009: AOD at $550 \mathrm{~nm}$ over OHP station modelled by the HadGEM2 climate model (bottom red line) and observed by the lidar from the tropopause to $20 \mathrm{~km}$ (bottom red crosses). The dates of the STAC flights are indicated in white in the upper panel. The black dashed line is the model thermal tropopause. The Sarychev eruption is symbolized by the red triangle.

The structure of the sulphate cloud is very similar to the $\mathrm{SO}_{2}$ distribution (Fig. 3) from the arrival of the aerosol plume on 24 June (day 175) until mid-August, when the $\mathrm{SO}_{2}$ plume vanishes. The first peak occurs on June 29-30 (days 179180) with a maximum AOD of 0.054 . Three other peaks in the AOD are present on 1 (day 182), 8 (day 189) and 12 July (day 193) also corresponding to $\mathrm{SO}_{2}$ peaks (Fig. 3). After mid-August no major peaks are modelled and aerosol 
amounts slowly decrease until late August where AOD values tend to recover near-background levels. The Kravitz et al. (2011) equation

$$
\frac{\mathrm{AOD} \text { at } 750 \mathrm{~nm} \text { and } r_{\mathrm{m}}=0.08-0.10 \mu \mathrm{m}}{\mathrm{AOD} \text { at } 550 \mathrm{~nm} \text { and } r_{\mathrm{m}}=0.08-0.10 \mu \mathrm{m}} \approx 0.30
$$

is used to derive a model AOD value equal to 0.016 at $750 \mathrm{~nm}$ for typical Sarychev aerosols over Kiruna with median radii in the $0.08-0.10 \mu \mathrm{m}$ range. Keeping in mind that the model does not consider background aerosols, this maximum value is in good agreement with the OSIRIS peak over Kiruna estimated to be of about 0.02 with a contribution of background aerosols of 0.0035 (Fig. 4). The peak in sulphate AOD on 30 June over Kiruna occurs about 1 month earlier than observed by OSIRIS (Fig. 4). This discrepancy has already been noticed by Haywood et al. (2010) and has been explained by a too fast transfer from an optically inactive Aitken mode to an optically active accumulation mode in the model aerosol scheme. Improvements of the CLASSIC aerosol scheme in HadGEM2 (Bellouin et al., 2007) are in progress to remedy this deficiency.

Lidar AOD integrated from the tropopause to $20 \mathrm{~km}$ and converted to $550 \mathrm{~nm}$ by using an Ångström exponent of 3.8 (Kravitz et al., 2011) is compared to the HadGEM2 AOD on the bottom of Fig. 7. The HadGEM2 AOD peak at the end of June is not present in lidar observations. Average HadGEM2 AOD over the 9 July-31 August period are found to be $25 \%$ higher than the average lidar AOD, with $6.4 \times 10^{-3}$ against $5.1 \times 10^{-3}$.

The vertical extent of the Sarychev plume is well established up to $19-20 \mathrm{~km}$. The lower part of the plume is in phase with the tropopause vertical dynamics, which is controlled by the alternating upper troughs as also shown in the observations. The model confirms that these low pressures lead to efficient transport of the lower stratospheric aerosols to altitudes lower than $5 \mathrm{~km}$. This dynamical process was particularly important during the mid-August period corresponding to the MicroRADIBAL flight.

Figure 8 shows cross sections of the HadGEM2 AOD over Europe on 2, 7, 18, and 24 August 2009 representing four different snapshots of the atmosphere during the StraPolÉTé campaign (black cross, Kiruna station). AOD has been calculated only for the Sarychev aerosols present from the surface to $\sim 20 \mathrm{~km}$. High levels of aerosols are continuously present for latitudes higher than $80^{\circ} \mathrm{N}$, with high variability from one day to another above Kiruna. These aerosols are more or less effectively transported southward depending on the meteorological conditions. On 2 August high levels of aerosols are present over western Europe as far as the north of Spain and over eastern Europe from Scandinavia to the Black Sea. Central Europe shows lower amounts of aerosols explained by a tropical intrusion. Kiruna is on the edge of a bulk of lower values. On 7 August the tropical intrusion is extended northward and entirely covers Scandinavia up to the Kiruna region. On 18 August the tropical intrusion has completely vanished and is replaced by a high-latitude air mass tongue full of sulphate aerosols and covering the Baltic Sea region and the Russian coasts. On 24 August, a less pronounced air mass intrusion coming from latitudes higher than $80^{\circ} \mathrm{N}$ is present over the Kiruna region. These last two intrusions are responsible for temperature increase observed with meteorological soundings from 9 to 20 August and on 24 August (Fig. 9), which is the typical signature of middle stratosphere air masses.

Figure 10 shows the HadGEM2 sulphur mass cross sections at $14 \mathrm{~km}$ and the potential vorticity field computed by the MIMOSA advection contour model (Hauchecorne et al., 2002) at $380 \mathrm{~K}$, for 7 and 24 August, respectively. On $7 \mathrm{Au}-$ gust the tropical intrusion is present in both models. On 24 August Fig. 10 shows the localized stratospheric intrusion from high latitudes that crossed central Europe. This intrusion with a high content of aerosols present over the Kiruna region is detectable down to $14 \mathrm{~km}$. These two examples show that the aerosol layers in the polar region between the tropopause and about $14-15 \mathrm{~km}$ are largely controlled by isentropic exchanges in the UTLS region.

\section{Physical properties of the Sarychev aerosols in the Arctic summer stratosphere}

The size-resolved number concentration measurements by STAC and the MicroRADIBAL radiance diagrams are fitted with either unimodal or bimodal lognormal size distributions of the form (Renard et al., 2002; Brogniez et al., 2003)

$n(r)=\sum_{i=1}^{2} \frac{N_{i}}{\ln \left(\sigma_{i}\right) \cdot \sqrt{2 \pi}} \cdot \frac{1}{r} \cdot \exp \left[-\frac{\ln ^{2}\left(r / r_{i}\right)}{2 \cdot \ln ^{2}\left(\sigma_{i}\right)}\right]$

in $\mathrm{cm}^{-3} \mu \mathrm{m}^{-1}$, where $N_{i}\left(\mathrm{~cm}^{-3}\right)$ is the total aerosol number density, $r_{i}(\mu \mathrm{m})$ is the aerosol median radius, and $\sigma_{i}$ is the geometric standard deviation of the distribution. In a stratosphere impacted by the Sarychev eruption, namely below $19 \mathrm{~km}$ as shown above, sulphate aerosols largely dominate and are expected to be mainly described by unimodal size distributions (Kravitz et al., 2011).

Distribution moments are derived using well-known analytical expressions. Using a statistical approach as described in Deshler et al. (2003), STAC counting uncertainties (Poisson statistics and the $\pm 10 \%$ precision) translate into uncertainties on distribution moments, with estimated values of $35 \%$ for $r_{\text {eff }}, 40 \%$ for surface area density (SAD), $40 \%$ for sulphur mass, and $40 \%$ for extinction. 

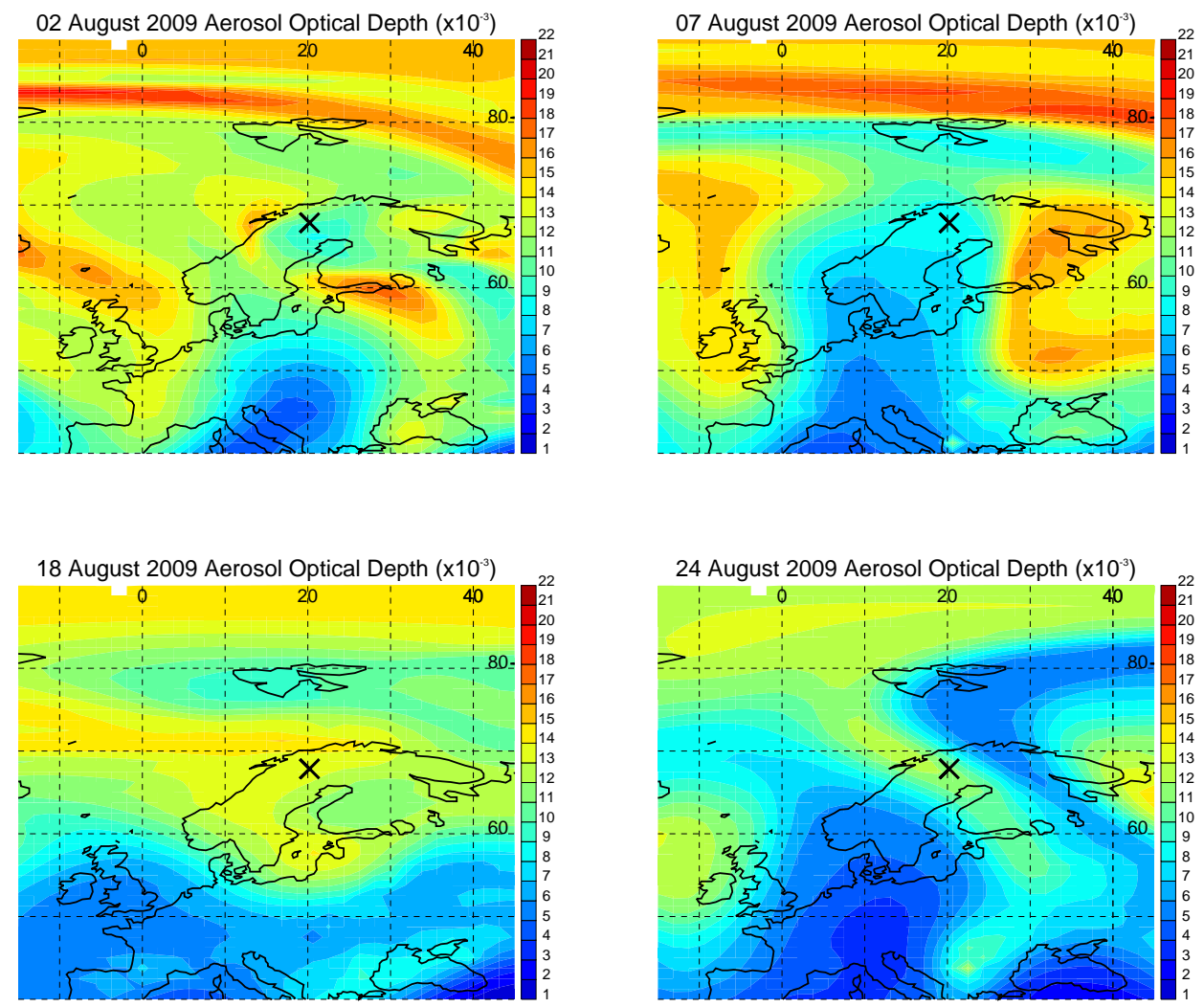

Fig. 8. HadGEM2 aerosol optical depth at $550 \mathrm{~nm}$ on 2, 7, 18, and 24 August 2009 over Europe (black cross: Kiruna station). AOD values are only for the Sarychev aerosols present from the surface to around $20 \mathrm{~km}$.

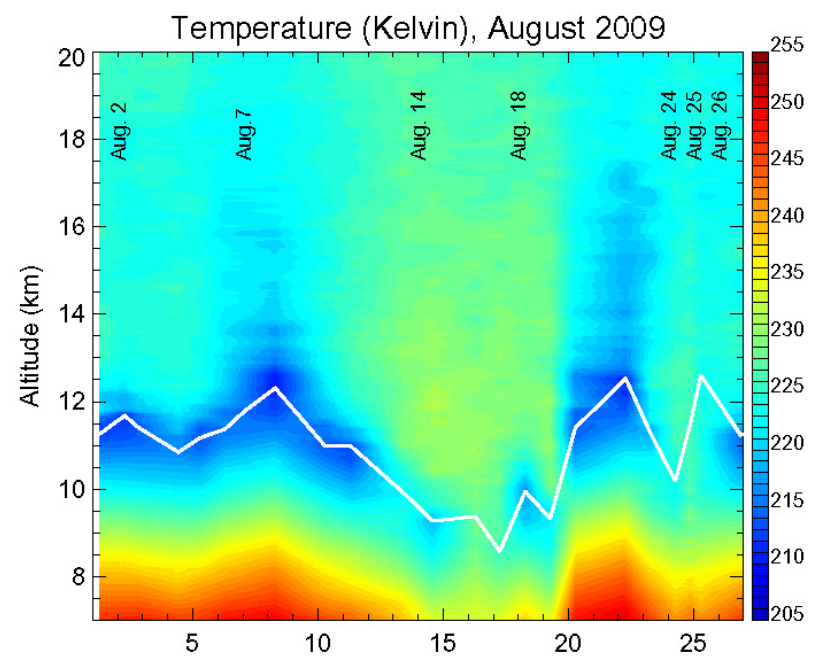

Fig. 9. Evolution of the temperature and thermal tropopause height (white line) from ozone-sonde observations in August 2009. The dates of the STAC flights are indicated in black.
Signatures attributed to solid aerosols were detected for altitudes above $19 \mathrm{~km}$ (Renard et al., 2010), confirming previous balloon-borne observations in the middle stratosphere (Renard et al., 2005, 2008). STAC is calibrated to provide size distributions of non-absorbing spherical aerosols, which result in indeterminable errors for the sizing of the solid nonspherical particles and the derived size distribution moments. Moreover, solid aerosols are not taken into account in the HadGEM2 model. In the following, we will therefore limit our study of the STAC, MicroRADIBAL, SALOMON, and OSIRIS measurements to the lower stratosphere in order to focus only on the Sarychev aerosols.

Large aerosol concentration enhancements were reported by Renard et al. (2010) from the summer 2009 STAC counting measurements in the lower stratosphere (see their Fig. 3), unambiguously demonstrating the impact of the Sarychev eruption. From these results, cumulated aerosol concentrations (particles with radii greater than $0.20 \mu \mathrm{m}$ ) are increased by a factor of 2-7 in comparison to the background situation in the April-May 2010 period.

The retrieved effective radius, extinction, $\mathrm{SAD}$, and sulphur mass as a function of altitude on $2,7,14,18,24$, 25, 26 August, 7 September 2009 (volcanic conditions), and 19 May 2010 (background conditions) are shown in Ta- 

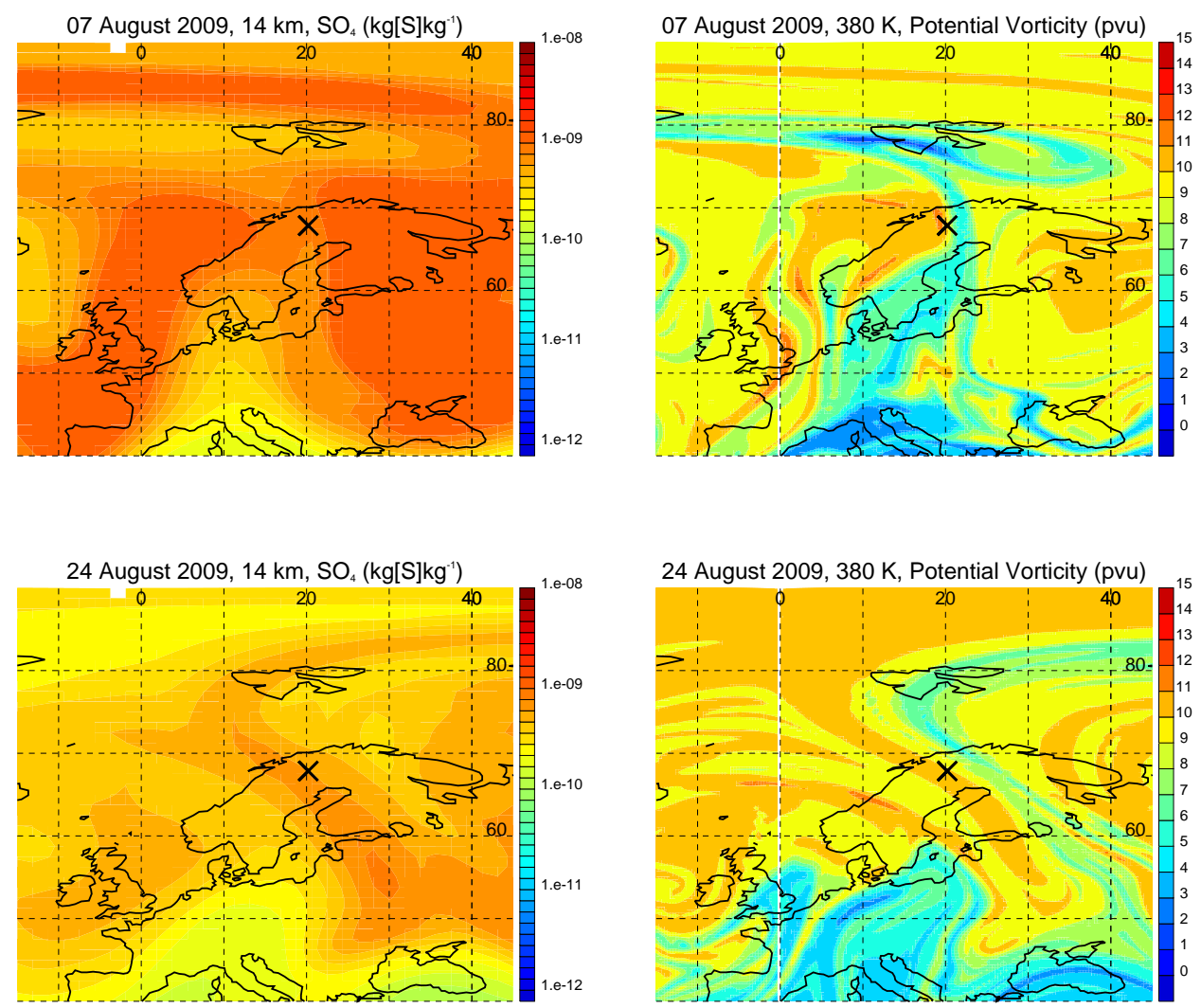

Fig. 10. HadGEM2 sulphur mass in $\mathrm{kg}[\mathrm{S}] / \mathrm{kg}[$ air] at $14 \mathrm{~km}$ (left) and potential vorticity (pvu) at $380 \mathrm{~K}$ from the MIMOSA model (right) on 7 (top) and 24 (bottom) August 2009.

ble 1 and for a selected number of days in Fig. 11 and Fig. 12. In these figures, black and red squares represent the STAC profiles obtained during balloon ascent and descent, respectively. Also represented are the SALOMON (black dashed lines) and OSIRIS (green lines) extinction profiles (Fig. 11). Results from observations by the MicroRADIBAL photopolarimeter are compared to the STAC observations on 18 August (see also Table 2). To achieve these comparisons, STAC observations are averaged over $\pm 250 \mathrm{~m}$ around the MicroRADIBAL altitudes to represent the MicroRADIBAL field of view. Thus, in Table 2 , numbers in brackets are $3 \times$ standard deviations corresponding for STAC to the spatial variability of the observations and for MicroRADIBAL to the uncertainties. In both figures the horizontal black dashed lines represent the thermal tropopause height derived from collocated balloon soundings. The $18 \mathrm{~km}$ level is close to the top of the sulphate layer.

\subsection{Effective radius}

The profile on 7 August (Fig. 11, top panel) shows high variability, with $r_{\text {eff }}$ values within the $0.09-0.28 \mu \mathrm{m}$ range. On 18 August the profile shows less variability, with $r_{\text {eff }}$ reaching $0.21 \mu \mathrm{m}$ at $14 \mathrm{~km}$. On 18 August in the $17-19 \mathrm{~km}$ alti- tude range the MicroRADIBAL and STAC $r_{\text {eff }}$ are $0.17 \mu \mathrm{m}$ and $0.15 \mu \mathrm{m}$, respectively (Table 2). High values between 0.3 and $0.4 \mu \mathrm{m}$ are present for STAC above the tropopause on 25 August. The last observations on 26 August and on 7 September show low values around $0.12 \mu \mathrm{m}$ over the whole altitude range. On average, values of $r_{\text {eff }}$ range from 0.15 to $0.20 \mu \mathrm{m}$ in summer 2009. The background conditions on 19 May 2010 are characterized by steady stratospheric $r_{\text {eff }}$ values of $0.15 \pm 0.01 \mu \mathrm{m}$. Observations in August 2009 show in general higher values.

An enhancement of $r_{\text {eff }}$ usually follows a volcanic eruption. For example, after the Pinatubo eruption $r_{\text {eff }}$ increased from $\sim 0.22 \mu \mathrm{m}$ to $0.5 \mu \mathrm{m}$ around $20 \mathrm{~km}$ (Bauman et al., 2003). Such an enhancement was observed by O'Neill et al. (2012), with $r_{\text {eff }}$ values of $0.183 \mu \mathrm{m}$ and $0.25 \mu \mathrm{m}$ before and after the Sarychev plume arrival over Greenland. Two months after the eruption, the maximum mean $r_{\text {eff }}$ of $0.20 \mu \mathrm{m}$ inferred from STAC observations at $14 \mathrm{~km}$ (Table 1) is lower than the results of O'Neill et al. (2012) but is higher than the expected values for background conditions. 

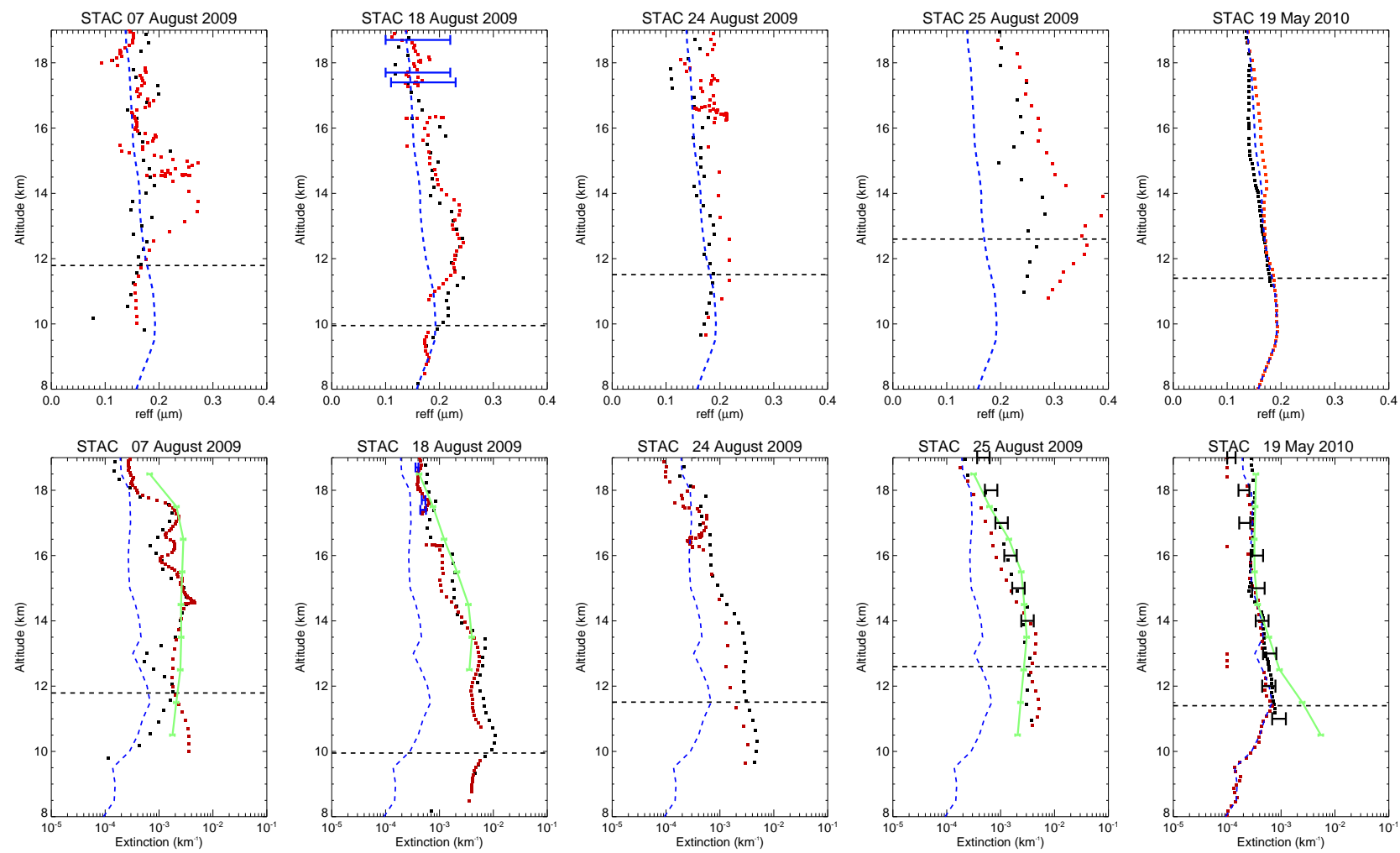

Fig. 11. Observations by the STAC aerosol counter for effective radius (top) and aerosol extinction coefficient at $740 \mathrm{~nm}$ (bottom) on 7 , 18, 24, and 25 August 2009 (volcanic conditions) and on 19 May 2010 (background conditions) for the balloon ascent (black squares) and descent (red squares). Dashed blue lines: STAC background profiles on 19 May 2010 averaged over the whole flight (ascent and descent). Horizontal blue lines: MicroRADIBAL effective radius and extinction coefficient at $740 \mathrm{~nm}$ in the $17-19 \mathrm{~km}$ range on 18 August 2009 . Extinction: OSIRIS profiles (green lines) at $750 \mathrm{~nm}$; SALOMON balloon observations (horizontal black lines) at $750 \mathrm{~nm}$ on $25 \mathrm{August} 2009$ and on 28 April 2011 (shown on the 19 May 2010 figure). Horizontal black dotted lines: thermal tropopause derived from collocated balloon soundings. See Sect. 6 for uncertainties.

\subsection{Extinction}

Mie theory (Van de Hulst, 1957) has been used to calculate aerosol extinction profiles and optical depths at $740 \mathrm{~nm}$ from the STAC granulometries on 7, 18, 24, 25 August 2009, and 19 May 2010. These extinction profiles are compared with individual OSIRIS profiles at $750 \mathrm{~nm}$, with extinction values derived at $740 \mathrm{~nm}$ from MicroRADIBAL measurements on 18 August and with SALOMON measurements at $750 \mathrm{~nm}$ on 25 August (Fig. 11, bottom panel). The OSIRIS profiles have been selected within a $10^{\circ}$ lat-long box around Kiruna to approximately coincide with the STAC flight profiles. The OSIRIS lat-long sampling is sufficient to provide comparisons for all STAC flights (except for 24 August, where no coincidence has been found) from 10-12 km height to $19 \mathrm{~km}$.

Figure 11 globally shows decreasing extinction values from the tropopause to $19 \mathrm{~km}$. OSIRIS average values are within $1 \%$ of the STAC average values at $14 \mathrm{~km}$ and are $52 \%$ and $26 \%$ larger than STAC at 16 and $18 \mathrm{~km}$, respectively (Table 1). The difference between STAC extinction values between ascent and descent somewhat reflects the strong lo- cal variability (over tens of $\mathrm{km}$ and a $2 \mathrm{~h}$ time interval) of the Sarychev aerosol content, certainly resulting from dynamical effects. The MicroRADIBAL aerosol extinction values on 18 August obtained during the balloon descent is on average $14 \%$ below the STAC descent profile (Table 2a).

On 25 August there is reasonable agreement between SALOMON extinction and OSIRIS (considering the error bars on the balloon data). Differences between OSIRIS and SALOMON values are $-11 \%,+22 \%$, and $-31 \%$ at 14,16 , and $18 \mathrm{~km}$, respectively. STAC data are comparable to both datasets, with once again some variability between ascent and descent in situ observations by STAC. The SALOMON extinction profile obtained on 28 April 2011 and overplotted on the 19 May 2010 panel in Fig. 11 is a new example of background conditions, again consistent with OSIRIS and STAC profiles, except near the tropopause, where OSIRIS deviates from the others.

This discrepancy around the tropopause could be the sign of local cirrus layers since no similar enhancements are present around the tropopause in the nearest OSIRIS pro- 

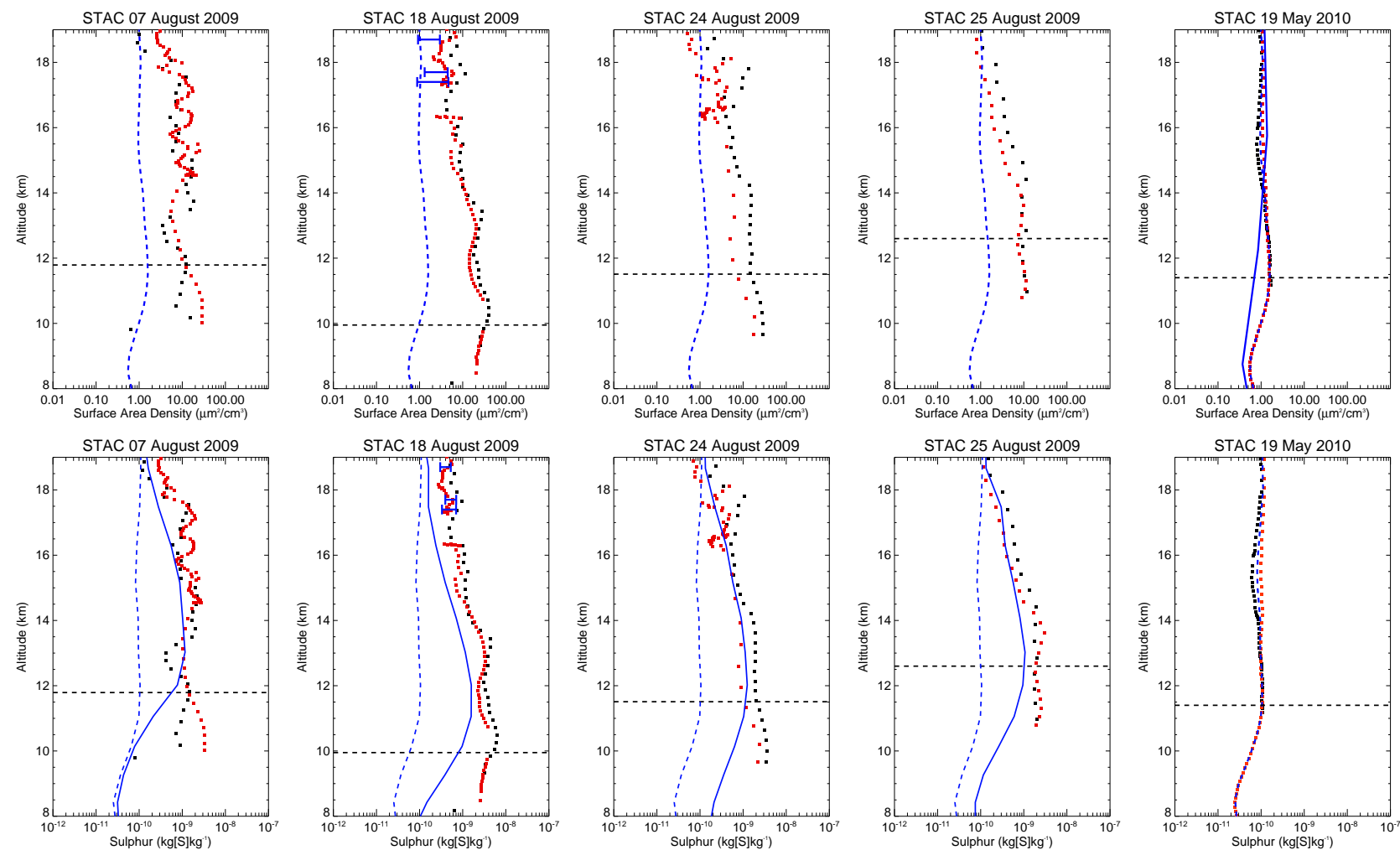

Fig. 12. Observations by the STAC aerosol counter for SAD (top) and sulphur mass (bottom) on 7, 18, 24, and 25 August 2009 (volcanic conditions) and on 19 May 2010 (background conditions), for the balloon ascent (black squares) and descent (red squares) balloon flights. Dashed blue lines: STAC background profiles on 19 May 2010 averaged over the whole flight (ascent and descent). Horizontal blue lines: MicroRADIBAL SAD and sulphur mass in the 17-19 km range on 18 August 2009. Sulphur mass: full blue lines correspond to the HadGEM2 profiles added to the 19 May 2010 STAC background profile. SAD: full blue line on 19 May 2010 is the typical SPARC ASAP scenario background aerosol profile (Weisenstein and Bekki, 2006). Horizontal black dotted lines: thermal tropopause derived from collocated balloon soundings. See Sect. 6 for uncertainties.

files (not shown). On average, extinction values observed by STAC in aerosol background conditions are reduced by a factor of about 7 and 2 at $14 \mathrm{~km}$ and $18 \mathrm{~km}$, respectively, in comparison with the summer 2009 observations (Table 1).

To retrieve the aerosol properties from the ACE-FTS instrument on board the SCISAT satellite, Doeringer et al. (2012) assume that the Sarychev volcanic aerosols in July 2009 have a constant $\sigma$ of 1.8 , while the median radius derived by a least-squares fit procedure is variable and equal to $\sim 0.09 \mu \mathrm{m}$ at $15 \mathrm{~km}$. In this case the effective radius is $0.21 \mu \mathrm{m}$. Average atmospheric extinction profiles at $1030 \mathrm{~nm}$ in July between 2004 and 2009 are shown in Doeringer et al. (2012). In July 2009, the aerosol layer is present approximately between $8.5 \mathrm{~km}$ and $17.5 \mathrm{~km}$ with a maximum extinction value of $2.8 \times 10^{-3} \mathrm{~km}^{-1}$ at an altitude of $13 \mathrm{~km}$. The usual atmospheric extinction at this altitude is about $4 \times 10^{-4} \mathrm{~km}^{-1}$, almost one order of magnitude smaller. The STAC measurements confirm this ratio with a mean extinction value at $15 \mathrm{~km}$ in August 2009 of $2.1 \times 10^{-3} \mathrm{~km}^{-1}$ compared to $3 \times 10^{-4} \mathrm{~km}^{-1}$ on 19 May 2010 .

\subsection{Surface area density}

SAD $\left(\mu \mathrm{m}^{2} \mathrm{~cm}^{-3}\right)$ is calculated by using the STAC and MicroRADIBAL distributions (Fig. 12, top panel). The STAC background profile on 19 May 2010 is characterized by a minimum of $0.5 \mu \mathrm{m}^{2} \mathrm{~cm}^{-3}$ at $9 \mathrm{~km}, 2.5 \mu \mathrm{m}^{2} \mathrm{~cm}^{-3}$ at the tropopause, and almost constant from 15 to $18 \mathrm{~km}$ with $1.0 \mu \mathrm{m}^{2} \mathrm{~cm}^{-3}$ at $18 \mathrm{~km}$. This SAD profile is compared to the SPARC ASAP (Weisenstein and Bekki, 2006) profile computed by the AER-UPMC two-dimensional (2-D) model considering typical background scenarios of sulphate precursors (50 ppt of $\mathrm{SO}_{2}$ in the lowermost stratosphere and $512 \mathrm{ppt}$ of carbonyl sulphide at the surface). The AER-UPMC profile shows values around $0.4 \mu \mathrm{m}^{2} \mathrm{~cm}^{-3}$ at $9 \mathrm{~km}, 0.8 \mu \mathrm{m}^{2} \mathrm{~cm}^{-3}$ at the tropopause, and $1.2 \mu \mathrm{m}^{2} \mathrm{~cm}^{-3}$ at $18 \mathrm{~km}$. The main differences with the STAC observations are located around the tropopause region $(10-15 \mathrm{~km})$. This could once again reflect some variability of the UTLS background aerosols resulting from regional dynamical processes which are not taken into account in 2-D models (of course limited in terms of 
Table 1. STAC average values at 14,16 , and $18 \mathrm{~km}( \pm 1 \mathrm{~km})$ of effective radius $(\mu \mathrm{m})$, aerosol coefficient extinction at $740 \mathrm{~nm}\left(10^{-4} \mathrm{~km}^{-1}\right)$, $\operatorname{SAD}\left(\mu \mathrm{m}^{2} \mathrm{~cm}^{-3}\right)$, and sulphur mass $\left(10^{-10} \mathrm{~kg}[\mathrm{~S}] \mathrm{kg}^{-1}\right)$ on 2, 7, 14, 18, 24, 25, 26 August, 7 September 2009, and $10 \mathrm{May} 2010 . *$ : ratio between the summer 2009 mean value (StraPolÉTé campaign) and the 19 May 2010 background value (AEROWAVE campaign). OSIRIS extinction values at $750 \mathrm{~nm}$ in $10^{-4} \mathrm{~km}^{-1}$. HadGEM2 sulphur mass calculation in $10^{-10} \mathrm{~kg}[\mathrm{~S}] \mathrm{kg}^{-1}$. Numbers in brackets are standard deviations.

\begin{tabular}{|c|c|c|c|c|c|c|c|c|c|c|c|c|}
\hline & & \multicolumn{9}{|c|}{2009} & \multicolumn{2}{|l|}{2010} \\
\hline \multirow[t]{2}{*}{$r_{\mathrm{eff}}$} & $18 \mathrm{~km}$ & 0.12 & 0.15 & 0.17 & 0.15 & 0.16 & 0.22 & 0.12 & 0.15 & $0.15(0.04)$ & 0.14 & 1.0 \\
\hline & $14 \mathrm{~km}$ & 0.20 & 0.22 & 0.26 & 0.21 & 0.19 & 0.32 & 0.11 & 0.14 & $0.21(0.07)$ & 0.16 & 1.3 \\
\hline Extinction & $18 \mathrm{~km}$ & 7.3 & 8.1 & 3.2 & 5.2 & 2.8 & 3.9 & 7.4 & 3.7 & $5.5(4.3)$ & 2.7 & 2.0 \\
\hline \multirow{3}{*}{$\begin{array}{l}\text { Extinction } \\
\text { (OSIRIS) }\end{array}$} & $18 \mathrm{~km}$ & 7.2 & 13.9 & 3.8 & 5.9 & no data & 4.7 & 5.9 & 6.7 & $6.9(4.5)$ & 3.4 & 2.0 \\
\hline & $16 \mathrm{~km}$ & 12.4 & 27.6 & 18.0 & 16.7 & no data & 19.3 & 15.3 & 17.6 & $18.1(6.0)$ & 3.2 & 5.6 \\
\hline & $14 \mathrm{~km}$ & 27.7 & 25.7 & 31.0 & 37.2 & no data & 29.0 & 26.6 & 15.9 & $27.6(7.2)$ & 4.8 & 5.8 \\
\hline \multirow[t]{2}{*}{ SAD } & $18 \mathrm{~km}$ & 14.5 & 6.4 & 2.3 & 4.6 & 3.2 & 1.4 & 10.5 & 4.1 & $5.5(5.5)$ & 1.0 & 5.5 \\
\hline & $16 \mathrm{~km}$ & 19.2 & 11.2 & 6.0 & 6.3 & 2.7 & 3.1 & 15.2 & 8.0 & $8.2(6.5)$ & 1.0 & 8.2 \\
\hline Mass & $14 \mathrm{~km}$ & 10.0 & 12.6 & 2.0 & 12.4 & 8.1 & 11.5 & 17.0 & 8.9 & $12.6(6.4)$ & 1.6 & 7.9 \\
\hline \multirow{3}{*}{$\begin{array}{l}\text { Mass } \\
\text { (HadGEM2) }\end{array}$} & $18 \mathrm{~km}$ & 2.8 & 2.7 & 2.1 & 2.1 & 2.3 & 2.7 & 2.5 & 2.0 & $2.4(0.7)$ & & \\
\hline & $16 \mathrm{~km}$ & 5.1 & 7.5 & 4.0 & 3.5 & 5.3 & 5.1 & 5.2 & 4.9 & $5.1(1.6)$ & & \\
\hline & $14 \mathrm{~km}$ & 5.3 & 7.7 & 4.2 & 3.7 & 5.5 & 5.3 & 5.4 & 5.2 & $10.1(2.0)$ & & \\
\hline
\end{tabular}

spatial resolution). Nevertheless, the overall good agreement provides new confidence in the SPARC ASAP scenario.

SAD from STAC in August 2009 at the altitudes of the volcanic plume are enhanced by a factor of 5-10 on average in comparison with the background aerosol situation of May 2010 (Table 1). The MicroRADIBAL SAD on $18 \mathrm{Au}-$ gust 2009 are 30-60\% lower than the STAC SAD values (averaged to the MicroRADIBAL vertical resolution) between 17.4 and $18.7 \mathrm{~km}$ (Table 2a). This gap may partly reflect the limitation of the lognormal fitting procedure of the STAC size-resolved concentrations, which provides a significant number of mathematically acceptable solutions encompassing the particle sizes lower than the STAC size detection threshold (i.e. minimum radius of $0.2 \mu \mathrm{m}$ ). Also, as stated above, MicroRADIBAL is less sensitive to small particles. To illustrate this effect, we have calculated the surface area density values starting from the first particle size class typically detected by STAC, i.e. for radii greater than $0.2 \mu \mathrm{m}$. Note that the same comparisons are made with truncated total number concentrations (Table 2b). The discrepancy between STAC and MicroRADIBAL is reduced by a factor of 2 when comparing these truncated SAD values (Table $2 b$ ). For $17.4,17.7$, and $18.7 \mathrm{~km}$, the truncated SAD values from MicroRADIBAL are 15,20 , and $28 \%$ smaller than STAC, respectively. Another explanation for the differences between both datasets could be related to the issue of comparing in situ data (the aerosol counter) with remote-sensing observations obtained by integrating over tens of kilometres (MicroRADIBAL). Even in the case of datasets obtained simultaneously, such comparisons are likely to be flawed when the targeted stratospheric compound is spatially variable along the instrument line of sight, as already investigated for stratospheric chemical species (Berthet et al., 2007). The effect of comparing these different observation techniques is more apparent when observations are close to the top of the plume around $18 \mathrm{~km}$, where the sulphate aerosols are sparse and not continuously detected.

It is interesting to notice that STAC SAD values agree well with the values ranging from 5 to $10 \mu \mathrm{m}^{2} \mathrm{~cm}^{-3}$ between 14 and $18 \mathrm{~km}$ at the end of August 2009 estimated by Mattis et al. (2010) from Raman lidar observations over Leipzig (Germany, $51.4^{\circ} \mathrm{N}, 12.4^{\circ} \mathrm{E}$ ). Similar conclusions are obtained taking the balloon in situ observations of Kravitz et al. (2011), who present SAD values ranging from 3 to $10 \mu \mathrm{m}^{2} \mathrm{~cm}^{-3}$ in the lower stratosphere, though this dataset has been recorded 2-3 months after our observations, i.e. on 7 November 2009. 
Table 2. (a) STAC (average over $\pm 250 \mathrm{~m}$ ) and MicroRADIBAL values at $17.4,17.7$, and $18.7 \mathrm{~km}$ of effective radius ( $\mu \mathrm{m}$ ), aerosol extinction $\left(10^{-4} \mathrm{~km}^{-1}\right)$, sulphur mass $\left(10^{-10} \mathrm{~kg}[\mathrm{~S}] \mathrm{kg}^{-1}\right)$, and SAD $\left(\mu \mathrm{m}^{2} \mathrm{~cm}^{-3}\right)$ obtained during the balloon descent on 18 August 2009. (b) STAC (average over $\pm 250 \mathrm{~m}$ ) and MicroRADIBAL values of SAD $\left(\mu \mathrm{m}^{2} \mathrm{~cm}^{-3}\right)$ and partial total number $\left(\mathrm{cm}^{-3}\right)$ for particles with radii $>0.2 \mu \mathrm{m}$. Numbers in brackets are $3 \times$ standard deviations corresponding for STAC to the spatial variability of the observations and for MicroRADIBAL to the uncertainties.

\begin{tabular}{|c|c|c|c|c|c|c|c|c|}
\hline (a) & MicroRAD. & STAC & MicroRAD. & STAC & MicroRAD. & STAC & MicroRAD. & STAC \\
\hline Altitude & $r_{\text {eff }}$ & $r_{\mathrm{eff}}$ & Extinction & Extinction & SAD & SAD & Mass & Mass \\
\hline $18.7 \mathrm{~km}$ & $0.16(0.06)$ & $0.14(0.06)$ & $3.26(0.39)$ & $4.20(0.72)$ & $1.94(1.02)$ & $4.59(5.22)$ & $4.15(1.14)$ & $4.15(2.94)$ \\
\hline $17.7 \mathrm{~km}$ & $0.16(0.06)$ & $0.15(0.03)$ & $4.94(0.24)$ & $5.70(1.74)$ & $2.90(1.59)$ & $4.85(3.12)$ & $5.51(1.56)$ & $4.53(2.16)$ \\
\hline $17.4 \mathrm{~km}$ & $0.17(0.06)$ & $0.16(0.03)$ & $5.06(0.60)$ & $5.40(1.38)$ & $2.77(1.89)$ & $4.17(1.68)$ & $5.17(1.86)$ & $4.07(1.68)$ \\
\hline (b) & \multicolumn{4}{|c|}{ for particles with $r>0.2 \mu \mathrm{m}$} & & & & \\
\hline Altitude & $\begin{array}{l}\text { MicroRAD. } \\
\text { SAD }\end{array}$ & $\begin{array}{l}\text { STAC } \\
\text { SAD }\end{array}$ & $\begin{array}{l}\text { MicroRAD. } \\
\text { N }\end{array}$ & $\begin{array}{l}\text { STAC } \\
\mathrm{N}\end{array}$ & & & & \\
\hline $18.7 \mathrm{~km}$ & $0.48(0.12)$ & $0.66(0.15)$ & $0.62(0.12)$ & $1.02(0.66)$ & & & & \\
\hline $17.7 \mathrm{~km}$ & $0.75(0.09)$ & $0.93(0.24)$ & $0.96(0.15)$ & $1.28(0.75)$ & & & & \\
\hline $17.4 \mathrm{~km}$ & $0.76(0.18)$ & $0.89(0.21)$ & $0.99(0.30)$ & $1.33(0.78)$ & & & & \\
\hline
\end{tabular}

\subsection{Sulphur mass}

The comparison between the STAC/MicroRADIBAL granulometries and the HadGEM2 model outputs is not directly feasible because the code is not designed to reproduce the evolution of the parameters of the aerosol distribution. On the other hand, the HadGEM2 model is indeed appropriate to follow the sulphur mass evolution. As stated above, background aerosols are not taken into account in the Sarychev eruption modelling. Thus, the mean aerosol profile observed by STAC on 19 May 2010 has been added to the HadGEM2 profiles to directly compare observations and model results. The sulphur mass profiles from observations and model (blue lines) calculations are shown in Fig. 12 (bottom panel). The dashed blue line represents the typical STAC profile in background conditions. This profile shows only small variations between $1 \times 10^{-10}$ and $2 \times 10^{-10} \mathrm{~kg}[\mathrm{~S}] \mathrm{kg}^{-1}$ from the tropopause to $18 \mathrm{~km}$. The difference between both blue lines in the August 2009 profiles quantifies the simulated aerosol enhancement resulting from the Sarychev eruption in terms of sulphur loading. On average, sulphur mass values observed by STAC in aerosol background conditions are reduced by a factor of about 8 and 3 at $14 \mathrm{~km}$ and $18 \mathrm{~km}$, respectively, in comparison with the summer 2009 observations (Table 1).

On the 7 and 18 August profiles, model calculations are lower than the STAC observations from 11 to about $15 \mathrm{~km}$, with a difference of $40-70 \%$ at $14 \mathrm{~km}( \pm 1 \mathrm{~km})$. For altitudes above, values from STAC are systematically 2-3 times higher. On 18 August, the sulphur loading values (see Table 2a) inferred from MicroRADIBAL observations above $17 \mathrm{~km}\left(4.9 \times 10^{-10} \mathrm{~kg}[\mathrm{~S}] \mathrm{kg}^{-1}\right.$ on average $)$ are about $16 \%$ larger than STAC values $\left(4.25 \times 10^{-10} \mathrm{~kg}[\mathrm{~S}] \mathrm{kg}^{-1}\right)$. Note that the difficulty to take into account accurately the contribution of the smaller particles to the calculated SAD values (see Sect. 6.3) may also apply to the calculation of the mass sulphur budget and consequently partly explain the discrepancies between the two instruments. However, overall better agreement is found in the sulphur mass (third-order moment) calculation than in the SAD (second-order moment) calculation (Table 2a). MicroRADIBAL and STAC observations at $18 \mathrm{~km}$ are $\sim 2$ times higher than the values computed by HadGEM2 $\left(2.1 \times 10^{-10} \mathrm{~kg}[\mathrm{~S}] \mathrm{kg}^{-1}\right.$, Table 1$)$, which returns to background quantities above $18 \mathrm{~km}$ corresponding to the top of the volcanic plume. This gap could either be due to too weak vertical transport of sulphate aerosols in the model or could reflect some variability in the background aerosol level. On 24 and 25 August, the sulphur mass profiles from STAC and HadGEM2 reasonably match from $2 \mathrm{~km}$ below the tropopause up to $19 \mathrm{~km}$ with average differences below $50 \%$. The observed and model profiles both return to background levels around $18 \mathrm{~km}$. On average in August, better results are found with model values of $20 \%, 30 \%$, and $50 \%$ below STAC at 14,16 , and $18 \mathrm{~km}$, respectively (Table 1). This result shows that the model, though not appropriate to calculate the high spatial variability of the STAC observations, succeeds in representing the aerosol trend over a month.

The modelled and STAC sulphur mass profiles show a maximum systematically $1.0 \pm 0.5 \mathrm{~km}$ above the tropopause, with values of $1-2 \times 10^{-9} \mathrm{~kg}[\mathrm{~S}] \mathrm{kg}^{-1}$ corresponding to an order of magnitude higher than the background level. STACHadGEM2 comparisons are difficult to perform below the tropopause because of the occurrence of cirrus clouds and spurious signals from tropospheric aerosols. When these effects are not present, as on 2 August (not shown), good agreement can be found between the model and STAC observations in the upper troposphere, suggesting reasonable tropospheric-stratospheric exchange computed in the HadGEM2 model. 
Overall, our results reveal acceptable agreement between the HadGEM2 model and the STAC observations in terms of sulphur mass values and vertical trend. This statement should be caveated by the fact that the model has a much broader spatial and temporal resolution than the STAC in situ observations and is consequently unable to describe the observed strong variability in the sulphate aerosol content.

\section{$7 \quad$ Discussion and conclusions}

Recent studies have shown that moderate volcanic eruptions (e.g. Soufriere Hills in Montserrat on May 2006) are likely to significantly contribute to increase the stratospheric aerosol loading over periods of months (Vernier et al., 2011) with non-negligible climate effects (Solomon et al., 2011). In this study, we have focussed on one of these moderate eruptions, the eruption of the mid-latitude Sarychev volcano, which injected on 15-16 June $2009 \sim 1 \mathrm{Tg}$ of $\mathrm{SO}_{2}$ into the stratosphere (Clarisse et al., 2012). With an e-folding time of $\sim 11$ days, the injected $\mathrm{SO}_{2}$ amounts were oxidized to gaseous sulphuric acid that almost immediately condensed into an $\mathrm{H}_{2} \mathrm{SO}_{4}-\mathrm{H}_{2} \mathrm{O}$ liquid aerosol in the stratosphere. This result differs from the Pinatubo eruption, where the e-folding time was estimated to range between 30 and 40 days (Bluth et al., 1997). The Sarychev perturbation is transient because the droplets fall out of the stratosphere with a characteristic efolding time of 80 days as shown from CALIOP and OSIRIS data. This e-folding time is significantly shorter than the 1214 month value estimated for the Pinatubo eruption (Baran et al., 1994; Oman et al., 2005). The latitude of the eruption is an important factor controlling this e-folding time since the volcanic aerosols are transported by the general circulation (Hamill et al., 1997). In the case of volcanic sulphate aerosols directly produced at mid- and high latitudes, as for the Sarychev event, their atmospheric lifetime is generally decreased. Indeed, our results indicate that a large part of the aerosol plume from the Sarychev eruption is concentrated in the mid-latitude storm tracks, where tropopause folding is responsible for a large part of the removal of stratospheric aerosols, in agreement with the conclusions of Kravitz et al. (2011).

In the 2009 Arctic summer, the StraPolÉté balloon campaign offered the opportunity investigate the physical properties of the Sarychev volcano aerosols within the UTLS region. Aerosol extinction profiles inferred from STAC observations during eight flights acceptably match extinction values measured by the OSIRIS UV-visible spectrometer and show significant extinction enhancements when compared to background conditions. MicroRADIBAL and SALOMON observations confirm these profiles during two flights. Note that the good agreement shown between OSIRIS extinction profiles and those derived from the balloon-borne instruments strengthens the OSIRIS retrieval hypothesis consisting in using a fixed mode radius $(0.08 \mu \mathrm{m})$ and a fixed width
(1.6) to derive extinction profiles even in such volcanic conditions (Bourassa et al., 2010). SAD values observed in the UTLS for the Sarychev period increase by a factor of 5-10 in comparison with background conditions. Such enhancements in SAD (typically implemented in chemistry-transport models) could have significant implications for stratospheric chemistry, in particular for nitrogen and halogenated species.

Though the HadGEM2 model provides reasonable simulations of $\mathrm{SO}_{2}$ transport and of its oxidation to sulphate aerosols, there are still some physical aspects that may require improvements. In particular, the transformation of optically inactive Aitken to optically active accumulation mode of sulphate appears too fast when compared to observations, possibly as a result of a lack of representation of nucleation processes. However, the vertical transport of the Sarychev sulphate aerosols is well modelled with a plume extending from the tropopause to about $19 \mathrm{~km}$, which is comparable to the results found with the OHP and CALIOP lidar measurements. Additionally, the sulphur mass calculated by the model over Kiruna is in reasonable agreement with the sulphur mass inferred from STAC and MicroRADIBAL observations with a maximum value of $1-2 \times 10^{-9} \mathrm{~kg}[\mathrm{~S}] \mathrm{kg}$ located $1.0 \pm 0.5 \mathrm{~km}$ above the tropopause, which is one order of magnitude higher than the background level. This indicates that the choice of a $1.2 \mathrm{Tg} \mathrm{SO}_{2}$ injection in the model to take into account all the June 2009 Sarychev eruptive events is consistent.

Vernier et al. (2011) state that the relatively high occurrence of this type of stratovolcano eruption in the tropical latitudes is likely to explain the worldwide increasing trend in aerosol backscatter of about 4-7\% per year $(0.015-$ $0.02 \mathrm{Tg}[\mathrm{S}] \mathrm{yr}^{-1}$ ) after 2000 above $20 \mathrm{~km}$ reported by Hofmann et al. (2009). However, this is somewhat a topic of debate since Hofmann et al. (2009) attributes this trend to increased emissions of $\mathrm{SO}_{2}$ (about $5.2 \%$ or $2.4 \mathrm{Tg}[\mathrm{S}]$ per year) from coal burning in Southeast Asia, ignoring a contribution from moderate eruptions. The impact on the stratosphere of mid-latitude moderate volcanic eruptions like Sarychev and Kasatochi is unambiguously recognized over periods of months, but an important issue is to quantify the contribution of the various potential sources of $\mathrm{SO}_{2}$ to the background aerosol loading, namely between two successive periods of volcanic influence on the stratosphere. OSIRIS observations presented in our study for periods free of volcanic aerosols, for instance before and after the Sarychev event, suggest a rather steady source, typically corresponding to $15-20 \%$ of the Sarychev AOD levels. Anthropogenic sources of $\mathrm{SO}_{2}$ and their variability should be quantified together with their transport pathways to the stratosphere so as to determine the contribution of these emissions to this stratospheric sulphate aerosol loading observed during volcanically quiescent periods. $\mathrm{SO}_{2}$ emissions from more frequent tropospheric volcanic eruptions (VEI $<4$ ), associated with tropospherestratosphere exchange dynamics (Holton et al., 1995), may be also a potential natural source to sustain a sulphate aerosol 
layer in the stratosphere and explain a part of its variability. Finally, these possible contributions of $\mathrm{SO}_{2}$ to the background stratospheric sulphur budget must be weighted with the role of carbonyl sulphide, the most abundant sulphur gas in the atmosphere (Barkley et al., 2008) and considered as a major precursor of stratospheric aerosols (Notholt and Bingemer, 2006). Model calculations by Brühl et al. (2012) even minimize the role of $\mathrm{SO}_{2}$ and estimate that upward transport of carbonyl sulphide from the troposphere largely controls the sulphur budget and the background aerosol loading of the stratosphere.

Thus, a renewed modelling effort including the latest $\mathrm{SO}_{2}$ emission data, simulations of tropical deep convection at various scales, complete tropospheric sulphur chemistry, and aerosol growth under changing vapour pressures in the stratosphere will be necessary to delineate the important mechanisms controlling the background aerosol layer. A new generation of light aerosol counters will also be necessary to monitor sudden events such as volcano eruptions and to discriminate the nature of the aerosols. The LOAC (Light Optical Aerosol Counter) is a new instrument developed in collaboration with the LPC2E laboratory (France) and the Environment S.A. company (France) capable of achieving this challenge during meteorological soundings. Such efforts need to be supported and improved by such international initiatives as the SSIRC (Stratospheric Sulphur and its Role in Climate) SPARC activity.

Acknowledgements. The authors thank the CNES balloon launching team for successful operations and the Swedish Space Corporation at Esrange. The ETHER database (CNES-INSUCNRS) and the CNES "sous-direction Ballon" are partners of the project. The StraPolÉté project has been funded by the French "Agence Nationale de la Recherche" (ANR-BLAN08-1-31627), the "Centre National d'Études Spatiales" (CNES), and the "Institut Polaire Paul-Emile Victor" (IPEV). The AEROWAVE (Aerosols, Water Vapor and Electricity) and the HALOHA (HALOgen in High Altitudes) projects have been funded by the recently created French CNES-INSU Balloon Committee (so-called CSTB). We are grateful to Slimane Bekki and David Cugniet for their constructive comments about the AER-UPMC 2-D model, to Marc-Antoine Drouin for his help about the MIMOSA model, and to the LPC2E technical team for this successful campaign. Jim Haywood and Andy Jones were supported by the Joint DECC/Defra Met Office Hadley Centre Climate Programme (GA01101). IASI was developed and built under the responsibility of the Centre National d'Études Spatiales (CNES, France). It is flown on board the Metop satellites as part of the EUMETSAT Polar System. The IASI L1 data are received through the EUMETCast near-real-time data distribution service. L. Clarisse is a postdoctoral researcher with FRS-FNRS. We acknowledge the CALIOP team for acquiring and processing data as well as the ICARE team for providing and maintaining the computational facilities to store them. Odin is a Swedish-led satellite project funded jointly by Sweden (SNSB), Canada (CSA), France (CNES), and Finland (Tekes). This study was supported by the French VOLTAIRE Labex (Laboratoire d'Excellence ANR-10-LABX-100-01) managed by the University of Orleans.

Edited by: A. Stohl

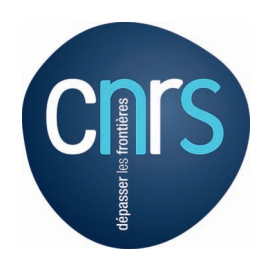

The publication of this article is financed by CNRS-INSU.

\section{References}

Baran, A. J. and Foot, J. S.: A new application of the operational sounder HIRS in determining a climatology of sulphuric acid aerosol from the Pinatubo eruption, J. Geophys. Res., 99, 2567325679, doi:10.1029/94JD02044, 1994.

Barkley, M. P., Palmer, P. I., Boone, C. D., Bernath, P. F., and Suntharalingam, P.: Global distributions of carbonyl sulfide in the upper troposphere and stratosphere, Geophys. Res. Lett., 35, L14810, doi:10.1029/2008GL034270, 2008.

Bauman, J. J.,Russell, P. B., Geller, M. A., and Hamill, P.: A stratospheric aerosol climatology from SAGE II and CLAES measurements: 2. Results and comparisons, 1984-1999, J. Geophys. Res., 108, 4383, doi:10.1029/2002JD002993, 2003.

Bellouin, N., Boucher, O., Haywood, J. M., Johnson, C., Jones, A., Rae, J., and Woodward, S.: Improved representation of aerosols for HadGEM2, Tech. Note 73, Met Office Hadley Centre, Exeter, UK, 2007.

Berthet, G, Renard, J.-B., Brogniez, C., Robert, C., Chartier, M., and Pirre, M.: Optical and physical properties of stratospheric aerosols from balloon measurements in the visible and nearinfrared domains. I. Analysis of aerosol extinction spectra from the AMON and SALOMON balloonborne spectrometers,, Appl. Optics, 41 7522-7539, 2002.

Berthet, G, Renard, J.-B., Catoire, V., Chartier, M., Robert, C., Huret, N., Coquelet, F., Bourgeois, Q., Rivière, E. D., Barret, B., Lefèvre, F., and Hauchecorne, A.: Remote sensing measurements in the polar vortex: comparison to in situ observations and implications for the simultaneous retrievals and analysis of the $\mathrm{NO}_{2}$ and OClO species, J. Geophys. Res., 112, D21310, doi:10.1029/2007JD008699, 2007.

Bluth, G. J. S., Doiron, S. D., Schnetzler, C. C., Krueger, A. J., and Walter, L. S.: Global tracking of the $\mathrm{SO}_{2}$ clouds from the June 1991 Mount Pinatubo eruptions, Geophys. Res. Lett., 19, 151154, doi:10.1029/91GL02792, 1992.

Bluth, G. J. S., Rose, W. I., Sprod, I. E., and Krueger, A. J.: Stratospheric loading from explosive volcanic eruptions, J. Geol., 105, 671-684, doi:10.1086/515972, 1997.

Bourassa, A. E., Degenstein, D. A., Elash, B. J., and Llewellyn, E. J.: Evolution of the stratospheric aerosol enhancement following the eruptions of Okmok and Kasatochi: OdinOSIRIS measurements, J. Geophys. Res., 115, D00L03, doi:10.1029/2009JD013274, 2010.

Bourassa, A., Robock, A., Randel, W., Deshler, T., Rieger, L., Lloyd, N., Llewellyn, E. J., and Degenstein, D.: Large Volcanic 
Aerosol Load in the Stratosphere Linked to Asian Monsoon Transport, Science, 337, 78-81, 2012a.

Bourassa, A. E., Rieger, L. A., Lloyd, N. D., and Degenstein, D. A.: Odin-OSIRIS stratospheric aerosol data product and SAGE III intercomparison, Atmos. Chem. Phys., 12, 605-614, doi:10.5194/acp-12-605-2012, 2012b.

Bourassa, A. E., McLinden, C. A., Bathgate, A. F., Elash, B. J., and Degenstein, D. A.: Precision estimate for OdinOSIRIS limb scatter retrievals, J. Geophys. Res., 117, D04303, doi:10.1029/2011JD016976, 2012c.

Brogniez, C., Huret, N., Eckermann, S., Rivière, E. D., Pirre, M., Herman, M., Balois, J.-Y., Verwaerde, C., Larsen, N., and Knudsen, B.: Polar stratospheric cloud microphysical properties measured by the microRADIBAL instrument on 25 January 2000 above Esrange and modeling interpretation, J. Geophys. Res., 108, 8332, doi:10.1029/2001JD001017, 2003.

Brühl, C., Lelieveld, J., Crutzen, P. J., and Tost, H.: The role of carbonyl sulphide as a source of stratospheric sulphate aerosol and its impact on climate, Atmos. Chem. Phys., 12, 1239-1253, doi:10.5194/acp-12-1239-2012, 2012.

Carslaw, K. C. and Kärcher, B.: Stratospheric aerosol processes, in Assessment of Stratospheric Aerosol Properties, edited by L. Thomason and T. Peter, WCRP 124, WMO/TD 1295, SPARC Rep. 4, World Meteorol. Organ., Geneva, Switzerland, 2006.

Clarisse, L., Coheur, P. F., Prata, A. J., Hurtmans, D., Razavi, A., Phulpin, T., Hadji-Lazaro, J., and Clerbaux, C.: Tracking and quantifying volcanic $\mathrm{SO}_{2}$ with IASI, the September 2007 eruption at Jebel at Tair, Atmos. Chem. Phys., 8, 7723-7734, doi:10.5194/acp-8-7723-2008, 2008.

Clarisse, L., Hurtmans, D., Clerbaux, C., Hadji-Lazaro, J., Ngadi, Y., and Coheur, P.-F.: Retrieval of sulphur dioxide from the infrared atmospheric sounding interferometer (IASI), Atmos. Meas. Tech., 5, 581-594, doi:10.5194/amt-5-581-2012, 2012.

Clerbaux, C., Boynard, A., Clarisse, L., George, M., Hadji-Lazaro, J., Herbin, H., Hurtmans, D., Pommier, M., Razavi, A., Turquety, S., Wespes, C., and Coheur, P.-F.: Monitoring of atmospheric composition using the thermal infrared IASI/MetOp sounder, Atmos. Chem. Phys., 9, 6041-6054, doi:10.5194/acp-9-6041-2009, 2009.

Collins, W. J., Bellouin, N., Doutriaux-Boucher, M., Gedney, N., Hinton, T., Jones, C. D., Liddicoat, S., Martin, G., O’Connor, F., Rae, J., Senior, C., Totterdell, I., Woodward, S., Reichler T., and Kim J.: Evaluation of the HadGEM2 model, Tech. Note 74, Met Office Hadley Centre, Exeter, UK, 2008.

d'Amico, G., Amodeo, A., Boselli, A., Giunta, A., Madonna, F., Mona, L., Pappalardo, G., Haywood, J., Jones, A., Bellouin, N., and Telford, P.: Stratospheric aerosol layers over southern Italy during the summer of 2009: Lidar observations and model comparison, paper presented at 25th International Laser Radar Conference, Int. Radiat. Comm., Int. Assoc. of Meteorol. and Atmos. Phys., St. Petersburg, Russia, 2010.

Deshler, T., Hervig, M. E., Hofmann, D. J., Rosen, J. M., and Liley, J. B.: Thirty years of in situ stratospheric aerosol size distribution measurements from Laramie, Wyoming $\left(41^{\circ} \mathrm{N}\right)$, using balloon-borne instruments, J. Geophys. Res., 108, 4167, doi:10.1029/2002JD002514, 2003.

Doeringer, D., Eldering, A., Boone, C. D., González Abad, G., and Bernath, P. F.: Observation of sulfate aerosols and $\mathrm{SO}_{2}$ from the Sarychev volcanic eruption using data from the Atmospheric
Chemistry Experiment (ACE), J. Geophys. Res., 117, D03203, doi:10.1029/2011JD016556, 2012.

Godin-Beekmann, S., Porteneuve, J., and Garnier, A.: Systematic DIAL lidar monitoring of the stratospheric ozone vertical distribution at Observatoire de Haute-Provence $\left(43.92^{\circ} \mathrm{N}, 5.71^{\circ} \mathrm{E}\right), \mathrm{J}$. Environ. Monit., 5, 57-67, 2003.

Hamill, P., Jensen, E. J., Russell, P. B., and Bauman, J. J.: The life cycle of stratospheric aerosol particles, B. Am. Meteorol. Soc., 78, 1395-1410, doi:10.1175/15200477(1997)078<1395:TLCOSA > 2.0.CO;2, 1997.

Hauchecorne, A., Godin, S., Marchand, M., Heese, B., and Souprayen, C.: Quantification of the transport of chemical constituents from the polar vortex to midlatitudes in the lower stratosphere using the high-resolution advection model MIMOSA and effective diffusivity, J. Geophys. Res., 107, 8289, doi:10.1029/2001JD000491, 2002.

Haywood, J. M., Jones, A., Clarisse, L., Bourassa, A., Barnes, J., Telford, P., Bellouin, N., Boucher, O., Agnew, P., Clerbaux, C., Coheur, P., Degenstein, D., and Braesicke, P.: Observations of the eruption of the Sarychev volcano and simulations using the HadGEM2 climate model, J. Geophys. Res., 115, D21212, doi:10.1029/2010JD014447, 2010.

Hofmann, D., Barnes, J., O’Neill, M., Trudeau, M., and Neely, R.: Increase in background stratospheric aerosol observed with lidar at Mauna Loa Observatory and Boulder, Colorado, Geophys. Res. Lett., 36, L15808, doi:10.1029/2009GL039008, 2009.

Holton, J. R., Haynes, P. H., McIntyre, M. E., Douglass, A. R., Rood, R. B., and Pfister, L.: stratosphere-troposphere exchange, Rev. Geophys., 33, 403-439, doi:10.1029/95RG02097, 1995.

Holton, J.: An Introduction to Dynamic Meteorology, 4th ed., 535 pp., Elsevier, Burlington, Mass, 2004.

Jones, A., Roberts, D. L., Woodage, M. J., and Johnson, C. E.: Indirect sulphate aerosol forcing in a climate model with an interactive sulphur cycle, J. Geophys. Res., 106, 20293-20310, doi:10.1029/2000JD000089, 2001.

Jones, A., Haywood, J., Boucher, O., Kravitz, B., and Robock, A.: Geoengineering by stratospheric $\mathrm{SO}_{2}$ injection: results from the Met Office HadGEM2 climate model and comparison with the Goddard Institute for Space Studies ModelE, Atmos. Chem. Phys., 10, 5999-6006, doi:10.5194/acp-10-5999-2010, 2010.

Klett, J. D.: Stable analytical inversion solution for processing lidar returns, Appl. Opt., 20, 211-220, doi:10.1364/AO.20.000211, 1981.

Kravitz, B., Robock, A., and Bourassa, A.: Negligible climatic effects from the 2008 Okmok and Kasatochi volcanic eruptions, J. Geophys. Res., 115, D00L05, doi:10.1029/2009JD013525, 2010.

Kravitz, B., Robock, A., Bourassa, A., Deshler, T., Wu, D., Mattis, I., Finger, F., Hoffmann, A., Ritter, C., Bitar, L., Duck, T. J., and Barnes, J. E.: Simulation and observations of stratospheric aerosols from the 2009 Sarychev volcanic eruption, J. Geophys Res., 116, D18211, doi:10.1029/2010JD015501, 2011.

Kristiansen, N. I., Stohl, A., Prata, A. J., Richter, A., Eckhardt, S., Seibert, P., Hoffmann, A., Ritter, C., Bitar, L., Duck, T. J., and Stebelet, K.: Remote sensing and inverse transport modeling of the Kasatochi eruption sulfur dioxide cloud, J. Geophys. Res., 115, D00L16, doi:10.1029/2009JD013286, 2010.

Krotkov, N. A., Schoeberl, M. R., Morris, G. A., Carn, S., and Yang, K.: Dispersion and lifetime of the $\mathrm{SO}_{2}$ cloud from the Au- 
gust 2008 Kasatochi eruption, J. Geophys. Res., 115, D00L20, doi:10.1029/2010JD013984, 2010.

Liu, Z., Vaughan, M., Winker, D., Kittaka, C., Getzewich, B., Kuehn, R., Omar, A., Powell, K., Trepte, C., and Hostetler, C.: The CALIPSO lidar cloud and aerosol discrimination: Version 2 algorithm and initial assessment of performance, J. Atmos. Oceanic Technol., 26, 1198-1213, 2009.

Llewellyn, E. J., Lloyd, N. D., Degenstein, D. A., Gattinger, R. L., Petelina, S. V., Bourassa, A. E., Wiensz, J. T., Ivanov, E. V., McDade, I. C., Solheim, B. H., McConnell, J. C., Haley, C. S., von Savigny, C., Sioris, C. E., McLinden, C. A., Griffioen, E., Kaminski, J., Evans, W. F. J., Puckrin, E., Strong, K., Wehrle, V., Hum, R. H., Kendall, D. J. W., Matsushita, J., Murtagh, D. P., Brohede, S., Stegman, J., Witt, G., Barnes, G., Payne, W. F., Piché, L., Smith, K., Warshaw, G., Deslauniers, D. L., Marchand, P., Richardson, E. H., King, R. A., Wevers, I., McCreath, W., Kyrölä, E., Oikarinen, L., Leppelmeier, G. W., Auvinen, H., Mégie, G., Hauchecorne, A., Lefèvre, F, de La Noë, J., Ricaud, P., Frisk, U., Sjoberg, F., von Schéele, F., and Nordh, L.: The OSIRIS instrument on the Odin spacecraft, Can. J. Phys., 82, 411-422, doi:10.1139/P04-005, 2004.

Mattis, I., Siefert, P., Müller, D., Tesche, M., Hiebsch, A., Kanitz, T., Schmidt, J., Finger, F. Wandinger, U., and Ansmann, A.: Volcanic aerosol layers observed with multiwavelength Raman lidar over central Europe in 2008-2009, J. Geophys. Res., 115, D00L04, doi:10.1029/2009JD013472, 2010.

Notholt J. and Bingemer, H.: Precursor Gas Measurements, in: Assessment of Stratospheric Aerosol Properties, edited by: Thomason, L. and Peter, T., WCRP 124, WMO/TD 1295, SPARC Rep. 4, World Meteorol. Organ., Geneva, Switzerland, 2006.

Oman, L., Robock, A., Stenchikov, G. L., Schmidt, G. A., and Ruedy, R.: Climatic response to high-latitude volcanic eruptions, J. Geophys. Res., 110, D13103, doi:10.1029/2004JD005487, 2005.

O’Neill, N. T., Perro, C., Saha, A., Lesins, G., Duck, T. J., Eloranta, E. W., Nott, G. J., Hoffman, A., Karumudi, M. L., Ritter, C., Bourassa, A., Abboud, I., Carn, S. A., and Savastiouk, V.: Properties of Sarychev sulphate aerosols over the Arctic, J. Geophys. Res., 117, D04203, doi:10.1029/2011JD016838, 2012.

Pommereau, J.-P. and Piquard, J.: Ozone and nitrogen dioxide vertical distributions by UV-visible solar occultation from balloons, Geophys. Res. Lett., 21, 1227-1230, 1994.

Renard, J.-B., Chartier, M., Robert, C., Chalumeau, G., Berthet, G., Pirre, M., Pommereau, J. P., and Goutail, F.: SALOMON: a new, light balloon borne UV-visible spectrometer for nighttime observations of stratospheric trace-gas species, Appl. Optics, 39, 386392, 2000

Renard, J.-B., Berthet, G., Robert, C., Chartier, M., Pirre, M., Brogniez, C., Herman, M., Verwaerde, C., Balois, J.-Y., Ovarlez, J., Ovarlez, H., Crespin, J., and Deshler, T.: Optical and physical properties of stratospheric aerosols from balloon measurements in the visible and near-infrared domain: 2. Comparison of extinction, reflectance, polarization and counting measurements, Appl. Opt., 41, 7540-7549, 2002.

Renard, J.-B., Berthet, G., Robert, C., Chartier, M., Pirre, M., Brogniez, C., Herman, M., Verwaerde, C., Balois, J.-Y., Ovarlez, H., Crespin, J., and Deshler, T.: Optical and physical properties of stratospheric aerosols from balloon measurements in the visible and near-infrared domains. III. Presence of aerosols in the middle stratosphere, Appl. Opt., 44, 4086-4095, doi:10.1364/AO.44.004086, 2005.

Renard, J.-B., Brogniez, C., Berthet, G., Bourgeois, Q., Gaubichet, B., Chartier, M., Balois, J.-Y., Verwaerde, C., Auriol, F., François, P., Daugeron, D., and Engrand, C.: Vertical distribution of the different types of aerosols in the stratosphere, Detection of solid particles and analysis of their spatial variability, J. Geophys. Res., 113, D21303, doi:10.1029/2008JD010150, 2008.

Renard, J.-B., Berthet, G, Salazar, S., Catoire, V., Tagger, T., Gaubicher, B., and Robert, C: In situ detection of aerosol layers in the middle stratosphere, Geophys. Res. Lett., 37, L20803, doi:10.1029/2010GL044307, 2010.

Robock, A.: Volcanic eruptions and climate, Rev. Geophys., 38, 191-219, doi:10.1029/1998RG000054, 2000.

Rybin, A, Chibisova, M., Webley, P., Steensen, T., Izbekov, P., Neal, C., and Realmuto, V.: Satellite and ground observations of the June 2009 eruption of Sarychev Peak volcano, Matua Island, Central Kuriles, Bull. Volcanol., 73, 1377-1392, doi:10.1007/s00445-011-0481-0, 2011.

Sawamura, P., Vernier, J. P., Barnes, J. E., Berkoff, T. A., Welton, E. J., Alados-Arboledas, L., Navas-Guzm'an, F., Pappalardo, G., Mona, L., Madonna, F., Lange, D., Sicard, M., Godin-Beekmann, S., Payen, G., Wang, Z., Hu, S., Tripathi, S. N., CordobaJabonero, C., and Hoff, R. M.: Stratospheric AOD after the 2011 eruption of Nabro volcano measured by lidars over the Northern Hemisphere, Environ. Res. Lett., 7, 034013, doi:10.1088/17489326/7/3/034013, 2012.

Solomon, S., Daniel, J. S., Neely III, R. R., Vernier, J.-P., Dutton, E. G., and Thomason, L. W.: The persistently variable "Background" stratospheric aerosol layer and global climate change, Science 333, 866, doi:10.1126/science.1206027, 2011.

Van de Hulst, H. C.: Light Scattering By Small Particles, John Wiley \& Sons, Inc., New York, 1957.

Vernier, J.-P., Thomason, L. W., Pommereau, J.-P., Bourassa, A., Pelon, J., Garnier, A., Hauchecorne, A., Blanot, L., Trepte, C., Degenstein, D., and Vargas, F.: Major influence of tropical volcanic eruptions on the stratospheric aerosol layer during the last decade, Geophys. Res. Lett., 38, L12807, doi:10.1029/2011GL047563, 2011.

Weisenstein, D. and Bekki, S.: Modeling of Stratospheric Aerosol, in: Assessment of Stratospheric Aerosol Properties, edited by: Thomason, L. and Peter, T., WCRP 124, WMO/TD 1295, SPARC Rep. 4, World Meteorol. Organ., Geneva, Switzerland, 2006.

Willeke, K. and Liu, B. Y. H.: Single particle optical counter: principle and application, in Fine Particles, Aerosol Generation, Measurement, Sampling and Analysis, B. Y. H. Liu, ed. Academic, Orlando, Fla., 698-729, 1976.

Winker, D. M., Hunt, W. H., and McGill, M. J.: Initial performance assessment of CALIOP, Geophys. Res. Lett., 34, L19803, doi:10.1029/2007GL030135, 2007.

Winker, D. M., Vaughan, M. A., Omar, A., Hu, Y., Powell, K. A., Liu, Z., Hunt, W. H., and Young, S. A.: Overview of the CALIPSO mission and CALIOP data processing algorithms, J. Atmos. Oceanic Technol., 26, 2310-2323, 2009. 